\begin{tabular}{ll}
\hline & $\begin{array}{l}\text { Kastamonu Eğitim Dergisi } \\
\text { Kastamonu Education Journal }\end{array}$ \\
$\begin{array}{l}\text { Eylül 2019 Cilt:27 Sayı:5 } \\
\text { kefdergi.kastamonu.edu.tr }\end{array}$ & Başvuru Tarihi/Received: 29.06 .2018 \\
Kabul Tarihi/Accepted: 09.11 .2018 \\
Dol: $10.24106 /$ kefdergi.3196
\end{tabular}

\title{
Ortak Bilgi Yapılandırma Modelinin Yedinci Sınıf Öğrencilerinin Elektrik Enerjisi Ünitesine İlişkin Kavramsal Anlamalarına Etkisi ${ }^{1}$
}

\section{The Effect of Common Knowledge Construction Model on Seventh Graders Students' Conceptual Understanding Related Electrical Energy Unit}

\author{
Belkız CAYMAZ², Abdullah AYDIN ${ }^{3}$
}

\section{Öz}

Bu araştırmanın amacı, Ortak Bilgi Yapılandırma Modeli (OBYM)'ne göre yürütülen fen öğretiminin yedinci sınıf öğrencilerinin kavramsal anlamalarına olan etkisini incelemektir. Araştırma, 2016-2017 eğitim-öğretim yılında deney grubunda yer alan 22 ve kontrol grubunda yer alan 20 öğrenci olmak üzere toplam 42 yedinci sını öğrencisi ile gerçekleştirilmiştir. Araştırmada, yedinci sınıf elektrik enerjisi ünitesi seçilmiştir ve yarı deneysel yönteme uygun olarak yürütülmüştür. Veri toplama aracı olarak, Elektrik Enerjisi Ünitesi Kavramsal Anlama Testi (EEÜKAT) kullanılmıştr. Araştırmadan elde edilen veriler, SPSS programı kullanılarak analiz edilmiştir. Konuların OBYM'ne göre işlendiği deney grubu öğrencilerinin EEÜKAT ön-test ve son-test puan ortalamaları arasında son-test lehine anlamlı bir farklıık olduğu bulunmuştur. OBYM'nin öğrencilerin kavramsal anlamaları üzerinde etkisinin daha net olarak ortaya çıkarılması için fen bilimleri dersinin farklı konularında modelin kullanılmasına yönelik araştırmaların yapılması önerilmektedir.

Anahtar Kelimeler: ortak bilgi yapılandırma modeli, kavramsal anlama, elektrik enerjisi, fen öğretimi

\section{Abstract}

The purpose of this study is to investigate the effect of science teaching based upon the Common Knowledge Construction Model (CKCM) on the conceptual understanding of 7th graders. The study was conducted with totally $427^{\text {th }}$ graders, 22 of whom were included in the experiment group and 20 of whom were in the control group in 2016-2017 academic year. The electrical energy unit in the curriculum of $7^{\text {th }}$ graders was selected in the study and it was conducted based on semi-experimental method. The Electrical Energy Unit Conceptual Understanding Test (EEUCUT) was used as the data collection tool. The data gathered in the study were analyzed via SPSS package program. A meaningful difference was revealed in favor of the post-test results between the pre-test and posttest results of the EEUCUT from the students in the experiment group where the lessons were taught according to CKCM. It is recommended that research should be conducted to use the model in different subjects of the science course in order to clarify the effect of CKCM on conceptual understanding of students.

Keywords: common knowledge construction model, conceptual understanding, electrical energy, science teaching 


\section{Extended Abstract}

The purpose of this study is to investigate the effect of science teaching based upon the Common Knowledge Construction Model (CKCM) on the conceptual understanding of 7th graders. The study was conducted with totally $427^{\text {th }}$ graders, 22 of whom were included in the experiment group and 20 of whom were in the control group in 2016-2017 academic year. The electrical energy unit in the curriculum of $7^{\text {th }}$ graders was selected in the study and it was conducted based on semi-experimental method. The Electrical Energy Unit Conceptual Understanding Test (EEUCUT) was used as the data collection tool. The data gathered in the study were analyzed via SPSS package program. A meaningful difference was revealed in favor of the post-test results between the pre-test and post-test results of the EEUCUT from the students in the experiment group where the lessons were taught according to CKCM.

It is aimed to question the conceptual understanding levels of $7^{\text {th }}$ graders regarding the electrical energy unit involved in the secondary school curriculum in this study. For this purpose, the problem statement of the research; "For this purpose, the problem statement of the research; "What are the effects of the use of CKCM-based course activities in the teaching of seventh graders students' conceptual understanding related electrical energy unit?". The sub-problems related to the solution of this problem are as follows:

Is there a significant difference between mean scores of EEUCUT of the experiment and control group students prior to the practice?

Is there a significant difference between mean scores of EEUCUT of the experiment and control group students at the end of the practice?

Is there a significant difference between mean scores of EEUCUT of the experiment group students before and after the practice?

Concepts are the basic keystones of science teaching and it is never expected for learning to be achieved without learning these concepts. The studies conducted beforehand show students come to these classrooms with some pre-knowledge regarding a concept or a natural event and this knowledge is mostly far from scientific truth (Duit and Treagust, 2003). In order to detect and eliminate these non-scientific opinions of the students, conceptual change approach should be used (Gilbert, Osborne and Fensham, 1982; Posner et al., 1982; Hewson \& Hewson, 1988; Hewson, 1992). The reason why the electrical energy unit was selected from the 7th graders' curriculum is because it involves the basic scientific concepts which students have difficulty in understanding, it includes many misconceptions on behalf of the students and because it covers subjects in conformity with the model and socio-scientific subjects. CKCM will help students understand and learn these subjects mentioned which they have difficulty in understanding and help them participate in classes, as well.

The semi-experimental method and pre-test post-test control group design was used in this study (Shadish, Cook and Champbell, 2002; Yıldırım and Şimşek, 2006). Two equivalent classrooms consisting of 7th graders in a secondary school located in the central district of Kastamonu were selected for the study. One of these classrooms was determined as the experiment, and the other as the control group randomly. While the students in the experiment group were taught the subjects in the unit based on the Common Knowledge Construction Model, no intervention was made in the control group and the subjects were taught according to the science curriculum. The study was conducted on totally 42 students being educated in the $7^{\text {th }}$ grade of a secondary school located in the central district of Kastamonu in 2016-2017 academic year, 22 of whom from the classroom 7A were randomly chosen as the experiment group and 20 of whom from the classroom 7B were randomly selected as the control group. One week before commencing the teaching of the electrical energy unit, the data collection tool was applied to both groups as the pre-test. Science lessons are given at secondary schools for 4 hours per week at total, 2 hours on two days. During the week prior to the practice, EEUCUT was applied as the pre-test in one lesson. Whereas the electrical energy unit was given to the control group according to the current curriculum, it was taught based on CKCM in the experiment group. The lessons lasted for totally 24 hours, four hours per week ( 6 weeks).

In this section, the findings and comments regarding the data obtained from EEUCUT applied to solve the sub-problems with the aim of investigating the effect of lessons based on CKCM on the students' conceptual understanding levels are given. In this regard, a meaningful difference was revealed between both groups in the pre-test scores. As for the post-test results, a meaningful difference was observed in favor of the experiment group. Following the practice, the mean scores of pre-test and post-test results of the EEU CUT test was examined both in the experiment and the control group. It was revealed there was an increase in the post-test scores of both groups, the post-test mean scores of the experiment group showed a higher rise than those of the control group and there was a meaningful difference in favor of the experiment group. In addition to the fact that the rise in the mean scores of the experiment group was higher, these students answered the questions in the conceptual understanding test more scientifically and using more profound explanations. As for the answers of the students in the control group, the answers they gave were less scientific, more superficial and involved more conceptual mistakes. When the literature is reviewed, it may be seen Ebenezer et al. (2010), İyibil (2011), Wood (2012), Kıryak (2013), Vural, Demircioğlu and Demircioğlu (2012), Bakırcı, Artun and Şenel, (2016) and Bakırcı and Ensari (2018) also reached similar conclusions in their studies.

| Kastamonu Eğitim Dergisi, 27(5), 2019| 


\section{Giriş}

Fen bilimleri dersinin temel kazanımlarından birisi de öğrencilerin kavramsal anlamalarını sağlamaktır (Biernacka, 2006; Wood, 2012). Kavramsal anlama; kavramlar arasında farklılıkların, benzerliklerin ve ilişkilerin kurulabildiği, bunların günlük ortamlara transfer edilebildiği ve sorunların çözümünde kullanılabildiği derinlemesine öğrenme olarak tarif edilebilir (Sinan, 2007). Fen bilimleri dersinde kavramsal anlamanın gerçekleşmesi, soyut kavramların somutlaştrııması, görsel materyallerin kullanılması ve farklı tekniklere yer verilmesi ile sağlanabilir. Fen derslerinin en büyük amacı kavramsal anlama olmasına rağmen, her yaştaki öğrencilerin çoğu bilimsel kavramları anlamada zorlanmaktadır (Gobert ve Clement, 1999; Bakırcı, Artun ve Şenel, 2016). Ortak Bilgi Yapılandırma Modeli (OBYM)'ne dayalı olarak yürütülen derslerin, bu konudaki eksikleri büyük oranda gidereceği düşüncesine inanılmaktadır (Bakırcı ve Çepni, 2012; Bakırcı, 2014; Ebenezer ve Connor, 1998; Biernacka, 2006; Ebenezer ve diğ., 2010). Bu durum, elektrik enerjisi ünite kapsamında yer alan konuların öğretiminde OBYM'nin kullanılmasının yedinci sınıf öğrencilerinin kavramsal anlamaları üzerinde etkisinin ortaya konulması açısından önem arz etmektedir. OBYM, yapılandırmacı öğrenme kuramını esas alan bir öğretim modeli olarak Ebenezer ve Connor tarafindan ilk olarak 1998 yılında geliştirilmiştir. Bu model dört temel aşamadan oluşmaktadır. Bu aşamalar aşağıdaki gibi sıralanabilir;

Keşfetme ve Sınıflandırma: Öğrenciler basit bir ya da iki etkinlikle kendi kişisel düşüncelerini keşfederler ve farklı görüşlerin açığa çıkması için teşvik edilirler. Düşünceleri doğru ya da yanlış olarak değerlendirilmez. Öğrencilerin, bilimin doğal olaylarını keşfetme ve açıklama girişimi olduğunu anladıkları evredir. Bu evrede araştırmacı, öğrenci görüşlerini kategorilere ayırır ve bu da hem dersi planlamada hem de işlemede kolaylık sağlamaktadır.

Yapılandırma ve Müzakere Etme: Bilimsel bilgiyi yapılandırma ve kavramların anlamını müzakere etme evresidir. Bu evrede öğretmen-öğrenci(ler) ve öğrenci-öğrenci etkileşiminin gerçekleşmesi oldukça önemlidir. Ne zaman öğretmen ve öğrenciler işbirliği içerisinde olursa, birlikte düşünür-araştrır ve müzakere ederse, o zaman geçerli kavramsal bilginin oluşumu ve yapılanması ve de işbirlikçi bilimsel araştırma tutumu kazanmış olurlar. Öğrenciler bilimsel bilginin sadece gözlem, deneysel kanıt ya da şüpheciliğe dayanmadığını; günlük hayatla ilişkili sorular sorduklarında, fikirlerini eleştirel düşünmeye açtklarında, bilimsel içeriği anlamlandırmada etkin bir yöntem olan çevredekilerle müzakereyi kullandıklarında kavramsal değişimin ortaya çıktğını fark ederler. Ayrıca öğrenciler, bilimsel görüşlerin yapılanmasında işbirliği içerisinde olmanın, sabır ve empati ile çabalamanın önemini fark ettikleri evredir.

Transfer Etme ve Genişletme: Öğrenci bu evrede, bir önceki evrede öğrendiklerini sosyobilimsel problemlerde kullanır. Bu evrede fenle ilgili sosyal problemlerin keşfi için öğrenciler teşvik edilir. Fen-teknoloji-toplum-çevre arasındaki kompleks etkileşimlere ilişkin farkındalık geliştirirler. Bunun için karışık, açık uçlu problemleri tanımlarlar, kişilerin probleme ilişkin görüşlerini açığa çıkarırlar, gerekli soruları sorarlar, sebeplerini ve sonuçlarını düşünürler, alternatif durumları düşünürler; yani eleştirel düşünme eğiliminde bulunurlar.

Yansıtma ve Değerlendirme: Bu model, alternatif öğretim yaklaşımlarının kullanıımasını önermektedir. Çünkü değerlendirme, öğrencinin nasıl keşfettiğini, nasıl kanıta dayalı kavramları gözden geçirdiğini ya da reddettiğini ölçebilmelidir. Zor olan fen kavramlarını anlamak için öğrencilerin kullandığı küçük adımları izlemek, kavramsal değişim için ne kadar etkili bir öğretim yapıldığına karar vermek, bir sonraki aşamada hangi kavramların keşfedileceğine karar vermek, öğrenilen kavramları nasıl kullandıklarını görmek, kişisel ve toplumsal ilgi gerektiren bilimsel ve sosyobilimsel konuları değerlendirmek için yapılır. Sürekli ve yansıtıcı öğrenme sürecinde, öğretmenler ve öğrenciler formatif değerlendirme içinde tutulmalıdır. Öğrencilerin ne bildiklerini, nasıl bildiklerini düşünmeleri sağlanmalıdır (Ebenezer ve Connor, 1998; Biernacka, 2006; Ebenezer ve diğ., 2010; Wood, Ebenezer ve Boone, 2013).

Fen bilimleri öğretiminde elektrik konusu temel ve önemli konulardan biridir. Bundan dolayı bu konunun öğretimi ve öğrenimi oldukça önem arz etmektedir (Gök ve diğ., 2009; Yılmaz ve Huyugüzel-Çavaş, 2006). Alanyazın incelendiğinde, bu konunun öğretiminde sıkıntılar yaşandığı ve soyut kavramlar içermesi sebebiyle öğrencilerin kavram yanılgılarına sahip oldukları görülmektedir (Akdeniz, Bektaş ve Yiğit, 2000; Dorneles, Veit ve Moreira, 2010; Ünsal ve Güneş, 2003; Yürümezoğlu ve Çökelez, 2010). Bu durum, öğrencileri bu konuda başarısızlığa dolaysıyla da genel olarak fen derslerine karşı isteksizliğe götürmektedir. Bundan dolayı öğrencilerin bu aşamada elektrik konusundaki kavram yanılgılarını gidermekle, onların lise ve üniversite eğitimi esnasında bu konuda başarısızlıklarının önüne geçilebilir (Demirci ve Efe, 2007; Aydın, 2016). OBYM ile ilgili yapılan çalışmaların sonuçları incelendiğinde; modelin alternatif kavramların belirlenmesinde, alternatif kavramların bilimsel kavramlarla değiştirilmesinde etkili olduğu (ìyibil, 2011; Wood, 2012; Kıryak, 2013) ve modelin kavramsal anlamayı sağladığı (Biernacka, 2006; Wood, 2012; Kıryak, 2013; Bakırcı ve Çepni, 2012) sonucuna varılmıştr. Dolaysıyla, OBYM'nin yedinci sınıf öğrencilerinin elektrik enerjisi ünite konularında kavramsal anlamaları üzerindeki etkisinin görülmesi bakımından literatüre önemli katkı sağlayacağı düşünülmektedir. 


\section{Araştırmanın Önemi}

İ̧̧inde bulunduğumuz bilgi ve teknoloji çağındaki değişimler ve gelişimler, fen eğitiminde de değişimi ve gelişimi gerekli kılmıştr. Bu sebeple, öğretmen merkezli eğitimden, öğrenci merkezli eğitime geçiş yapılmıştır. Öğrenciler, bilginin pasif alıcısı konumundayken, aktif yapılandırııısı konumuna geçmiştir ve anlamlı öğrenme ön plana çıkmıştr. Son yıllarda ilköğretim düzeyinde yapılan çalışmaların çoğunluğunu öğrencilerin kavramsal anlamaları ile ilgili yapılan çalışmalar oluşturmaktadır. Bu çalışmaların ortak noktası her konu alanı ile ilgili öğrencilerin kavram yanılgılarının belirlenerek, var olan yanılgıları gidermeye yönelik çeşitli yöntem ve teknikleri kullanmaktır (Psillos ve Kariotoglou, 1999; She, 2002; Besson, 2004; Ünal-Çoban, 2009). Kavramlar, fen eğitiminin temel yapıtaşlarıdır ve bu kavramlar öğrenilmeden anlamlı öğrenmenin gerçekleşmesi beklenemez. Yapılan çalışmalar, öğrencilerin bir kavrama ya da doğal olaya ilişkin birtakım ön bilgilerle sınıfa geldiğini, bu bilgilerin çoğunlukla bilimsel doğrulardan uzak olduğunu göstermektedir (Duit ve Treagust, 2003). Öğrencilerin kavramlara ilişkin bilimsel olmayan bu görüşlerini tespit edip gidermek için, kavramsal değişim yaklaşımı kullanılmalıdır (Gilbert, Osborne ve Fensham, 1982; Posner ve diğ., 1982; Hewson ve Hewson, 1988; Hewson, 1992). Fen eğitiminin etkili bir şekilde yürütülmesi için yeni yol veya yöntemlerin araştrılması ve keşfedilmesi gerekmektedir. Bunlardan birini de sosyal yapılandırmacılığı, fenomenografiyi, bilimin doğasını ve sosyo-bilimsel sorgulamayı sentezleyen OBYM oluşturmaktadır. Ulusal ve uluslararası düzeyde sınırlı bir uygulama alanına sahip olan OBYM ile ilgili yürütülen çalışmalar modelin etkili olduğunu göstermiştir.

Elektrik enerjisi ünitesi konuları ile ilgili literatürde çeşitli çalışmalara rastlamak mümkündür. Ancak yeni bir öğretim modeli olan ve birçok öğrenme teorisinin sentezinden oluşan OBYM ile ilgili yapılan çalışmaların içerisinde elektrik enerjisi ünite konularına yönelik öğrencilerin bilgi düzeylerini araştıran ve kavramsal anlamalarını sağlayan bu gibi çalışmaların alanyazına katkısı önemli olacaktır. Fen bilimleri dersinde çeşitli konularda birçok kavram yanılgısı mevcuttur. Kavram yanılgısı içeren konulardan biri de elektrik konusudur. Bu konu ile ilgili yapılan araştırmalar incelendiğinde ilkokul, ortaokul, lise ve üniversite öğrencilerinde hatta yetişkin birçok bireyde de elektrik konuları ile ilgili kavram yanılgılarının mevcut olduğu görülmüştür (Atlğanlar, 2014). Ayrıca, yedinci sınıf elektrik enerjisi ünitesi öğrencilerin anlamakta zorlandıkları temel fen ve soyut kavramları içermesi ve yaygın kavram yanılgılarının olması bakımından bu çalışmanın araştırma konusu olmuştur.. OBYM destekli öğretimin öğrencilerin anlamada güçlük çektikleri bu gibi konuları daha iyi anlamalarına, öğrenmelerine ve derse katılımlarına yardımcı olacağı düşünülmektedir.

\section{Araştırmanın Amacı}

Bu araştırmada, öğrencilerin bilgilerini yapılandırmalarına olanak tanıyan, onların öğrenme sürecinde aktif olmalarını sağlayan OBYM'nin fen bilimleri dersinde kullanılmasının ortaokul öğrencilerinin kavramsal anlamaları üzerindeki etkilerinin araştıılması amaçlanmıştır. Bu amaç doğrultusunda araştırmanın problem cümlesi; "OBYM'ye dayalı ders etkinliklerinin ortaokul yedinci sınıf elektrik enerjisi ünitesinin öğretiminde kullanılmasının öğrencilerin kavramsal anlamalarına etkileri nelerdir?" şeklinde ifade edilmiştir. Bu problemin çözümüne yönelik alt problemler ise;

Deney ve kontrol grubu öğrencilerinin uygulama öncesinde EEÜKAT puan ortalamaları arasında anlamlı bir fark var mıdır?

Deney ve kontrol grubu öğrencilerinin uygulama sonunda EEÜKAT puan ortalamaları arasında anlamlı bir fark var mıdır?

Deney grubu öğrencilerinin uygulama öncesi ve sonrasında EEÜKAT puan ortalamaları arasında anlamlı bir fark var mıdır?

\section{Yöntem}

Bu araştrrmada, deneysel araştırma yöntemlerinden ön-test son-test kontrol gruplu yarı deneysel desen kullanılmıştı (Shadish, Cook ve Champbell, 2002; Yıldırım ve Şimşek, 2006). Araştırma için, Kastamonu il merkezinde bir ortaokulun yedinci sınıflarından birbirine denk iki şube seçilmiştir. Bu şubelerden birisi deney, diğeri kontrol grubu olarak rastgele belirlenmiştir. Deney grubundaki öğrencilere elektrik enerjisi ünitesi konuları OBYM destekli etkinliklerle anlatlırken, kontrol grubundaki öğrencilere ise herhangi bir müdahalede bulunulmamış olup, konular 2013 Fen Bilimleri Dersi Öğretim Programı doğrultusunda anlatılmıştır. Araştırmanın deneysel modeli Tablo 1'de gösterilmiştir.

Tablo 1. Araştırmanın deneysel modeli

\begin{tabular}{llll}
\hline Gruplar & Ön-test & Uygulama & Son-test \\
\hline Deney Grubu & EEÜKAT & OBYM ile destekli & EEÜKAT \\
\hline Kontrol Grubu & EEÜKAT & 2013 Fen Bilimleri Dersi Öğretim Programına Uygun & EEÜKAT \\
\hline
\end{tabular}

| Kastamonu Eğitim Dergisi, 27(5), 2019| 


\section{Çalışma Grubu}

Araştırmanın çalışma grubunu, 2016-2017 eğitim-öğretim yılında Kastamonu il merkezinde bulunan bir ortaokulun yedinci sınıflarında öğrenim gören öğrenciler oluşturmaktadır. Çalışma grubunun belirlenmesinde araştrmaya hız ve pratiklik kazandıran kolay ulaşılabilir örneklem yöntemi kullanılmıştı (Yıldırım ve Şimşek, 2006; Bakırcı, Artun ve Şenel, 2016). Karne notlarına göre akademik başarıları aynı iki sınıftan biri deney grubunu ( $N=22$ ) diğeri ise kontrol grubunu $(\mathrm{N}=20)$ oluşturmuştur. Deney grubunda 9 kı 13 erkek öğrenci, kontrol grubunda ise 11 kız, 9 erkek öğrenci bulunmaktadır. Çalışma grubunu oluşturan öğrencilerin demografik özellikleri Tablo 2'de verilmiştir.

Tablo 2. Çalışma grubundaki öğrencilerin demografik özellikleri

\begin{tabular}{lcccc}
\hline & \multicolumn{3}{c}{ Cinsiyet } \\
\cline { 2 - 5 } Grup & \multicolumn{2}{c}{ Kız } & \multicolumn{3}{c}{ Erkek } \\
\cline { 2 - 5 } & $\mathbf{N}$ & $\%$ & $\mathbf{N}$ & $\%$ \\
\hline Kontrol & 11 & 55 & 9 & 45 \\
Deney & 9 & 40,9 & 13 & 59,1 \\
\hline
\end{tabular}

\section{Veri Toplama Araçları}

Elektrik enerjisi ünitesinin öğretiminde Ortak Bilgi Yapılandırma Modeli (OBYM)'nin kullanımının öğrencilerin kavramsal anlamalarına olan etkisini belirlemek amacıyla araştırmacılar tarafindan geliştirilen Elektrik Enerjisi Ünitesi Kavramsal Anlama Testi (EEÜKAT) kullanılmıştır. EEÜKAT; fen bilimleri dersi yedinci sınıf elektrik enerjisi ünitesindeki kazanımlar dikkate alınarak geliştirilmiştir. Ünitenin kavramları belirlenmiş, kavramların tanımları yapılmıştır. Bu kavramlarda gözlenen yaygın kavram yanılgıları oluşturulmuştur. Testin geliştirilmesi için alanyazın taraması yapılmış ve bu alanla ilgili geliştirilen ölçekler incelenmiştir. Test geliştirilmeden önce, elektrik enerjisi ünitesiyle ilgili öğrenci algılamalarını araştıran çalışmalar detaylı bir şekilde gözden geçirilmiştir. Bu araştırmalar, öğrencilerde var olan yaygın alternatif kavramlar ve bu kavramların giderilmesiyle ilgilidir. Öğrencilerin kavram yanılgıları tespit edilirken genellikle benzer zihinsel modeller dikkate alınmıştır (Osborne, 1983; Wang ve Andre, 1991; Chambers ve Andre, 1997; Sencar, Yılmaz ve Eryılmaz, 2001; Sencar ve Eryılmaz, 2002; Yıldırım ve diğ., 2008; Peşman ve Eryılmaz, 2010; Yürümezoğlu ve Çökelez, 2010). Bu araştırmada da test geliştirilirken literatürde bahsedildiği gibi Tablo 3'te gösterilen zihinsel modeller dikkate alınmıştr.

Tablo 3. Elektrik enerjisi ünitesi kavramsal anlama testinde yer alan soruların zihinsel modellere göre dağılımı

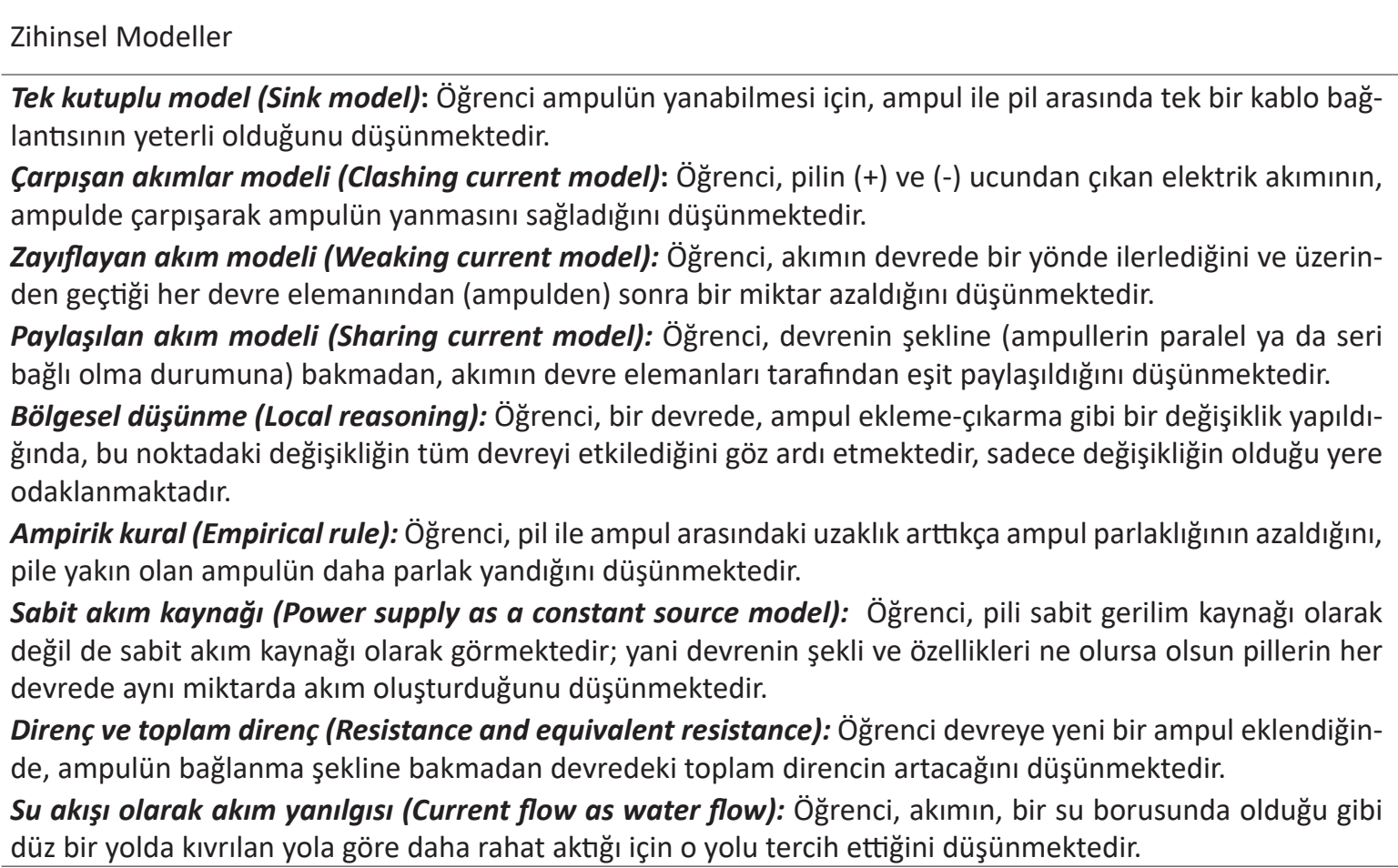
Soru No

Tablo 3 incelendiğinde EEÜKAT’nin geliştirilmesinde her bir zihinsel modele yönelik bir sorunun yer aldığı görül- 
mektedir. Testteki sorular hazırlanırken daha önceden farklı çalışmalarda geliştirilmiş elektrik kavramsal anlama testlerinden de faydalanılmıştı (Aydın, 2010; Peşman ve Eryılmaz, 2010; Küçük, 2011). EEÜKAT'de 9 adet çoktan seçmeli ve iki aşamalı sorular bulunmaktadır (Bulgular ve Yorumlar başlığında verilmiştir). Öğrenci, A), B) ve C) seçeneklerinden doğru olanı ve seçtiği seçeneği açıklayan ifadenin bulunduğu a), b) ve c) seçeneklerinden birini daha seçmesi gerekmektedir. Öğrenci kendisine sunulan gerekçelerden hiç birini uygun bulmazsa, o zaman kendi düşüncelerini yazabileceği d) seçeneği bulunmaktadır.

\section{Geçerlik ve Güvenirlik Çalışması}

EEÜKAT, kazanımlar dikkate alınarak iki aşamadan oluşmuştur. Testin birinci aşaması çoktan seçmeli seçeneklerden, ikinci aşaması ise birinci aşamada işaretlediği seçeneğin gerekçesini belirtmek zorunda olduğu cümlelerden oluşmaktadır. Eğer öğrenci, sunulan gerekçelerden hiçbirini cevabına uygun bulmazsa, son seçenekte (d) boş bırakılan yere kendi gerekçesini yazabilmektedir. Öğrencinin testin ikinci aşamasında, birinci aşamada işaretlediği seçeneğin gerekçesini belirtmek zorunda olması çoktan seçmeli soruların dezavantajı yönü olan doğru seçeneğin rastgele bulunma ihtimalini de azaltmaktadır.

Başlangıçta EEÜKAT'de14 adet soru yer almaktadır. Her bir sorunun hangi zihinsel modelle ilişkili olduğunun belirtildiği sorulardan oluşan bu test öncelikle ünite kazanımlarına ve öğrenci seviyesine uygunluk uzman görüşüne (2 akademisyen, 3 fen bilimleri öğretmeni) sunulmuştur. Daha sonra dilbilgisi ve anlaşıırlık bakımından da 1 Türkçe öğretmeninden görüş alınmıştrr. Öğrencilere uygulanacak olan bu test, uzmanlardan gelen görüşler doğrultusunda testteki soru sayısının 9'a düşürülmesi kararlaştırılmıştr. Ayrıca, Kastamonu il merkezindeki bir okuldan rastgele seçilen 5 öğrenci ile testteki her bir sorunun öğrenciler tarafindan anlaşılabilirliğini kontrol etmek amacıyla görüşme yapılmış ve öğrenciler tarafindan anlaşılamayan ya da farkıı algılanan ifadeler düzeltilerek uygulamaya hazır hale getirilmiştir. Bu şekilde hazırlanan testin hem birinci aşamasında hem de ikinci aşamasında doğru cevap veren öğrenciye 1 puan, yanlış cevap veren veya boş bırakan öğrenciye ise 0 puan verilmiştir.

EEÜKAT'nin güvenirlik çalışmasını yapmak için Kastamonu merkezde yer alan iki ortaokulda çalışma grubuna dahil olmayan sekizinci sınıf toplam 110 öğrenciye testin ön uygulaması yapılmış ve sonrasında madde analizine tabi tutulmuştur. Madde analizi yapılırken testte yer alan her bir maddenin madde ayırt edicilik ve madde güçlük indeksi hesaplanmıştr. Test iki aşamalı ve her aşama çoktan seçmeli olduğundan analiz yapılırken önce her aşama ayrı ayrı ve daha sonra iki aşama birlikte dikkate alınmıştır. Böylece, testteki maddeler hem derinlemesine hem de bütün olarak analiz edilmiştir. EEÜKAT'nin ön uygulamasında yer alan her bir maddenin aşamalar halinde ve bütün olarak madde ayırt edicilik indeksleri ve madde güçlük indeksleri Tablo 4'te sunulmuştur.

Tablo 4. EEÜKAT’nin madde analizi sonuçları

\begin{tabular}{|c|c|c|c|c|c|c|}
\hline \multirow[b]{2}{*}{ Madde No } & \multicolumn{2}{|c|}{ Birinci Aşama } & \multicolumn{2}{|c|}{ İkinci Aşama } & \multicolumn{2}{|c|}{ Birinci ve İkinci Aşama } \\
\hline & $\begin{array}{c}\text { Madde } \\
\text { Gücclük } \\
\text { İndeksi (p) }\end{array}$ & $\begin{array}{c}\text { Madde } \\
\text { Ayırtedicilik } \\
\text { Indeksi (r) }\end{array}$ & $\begin{array}{c}\text { Madde } \\
\text { Güçlük } \\
\text { İndeksi (p) }\end{array}$ & $\begin{array}{c}\text { Madde } \\
\text { Ayırtedicilik } \\
\text { Indeksi (r) }\end{array}$ & $\begin{array}{c}\text { Madde } \\
\text { Güçlük İndeksi } \\
\text { (p) }\end{array}$ & $\begin{array}{c}\text { Madde } \\
\text { Ayırtedicilik } \\
\text { Indeksi (r) }\end{array}$ \\
\hline 1. & 0,78 & 0,66 & 0,80 & 0,48 & 0,78 & 0,37 \\
\hline 2. & 0,80 & 0,53 & 0,67 & 0,47 & 0,64 & 0,54 \\
\hline 3. & 0,71 & 0,59 & 0,76 & 0,46 & 0,73 & 0,31 \\
\hline 5. & 0,52 & 0,37 & 0,53 & 0,34 & 0,53 & 0,40 \\
\hline 4. & 0,56 & 0,42 & 0,63 & 0,40 & 0,53 & 0,35 \\
\hline 6. & 0,82 & 0,47 & 0,81 & 0,36 & 0,73 & 0,44 \\
\hline 7. & 0,60 & 0,46 & 0,60 & 0,50 & 0,61 & 0,50 \\
\hline 8. & 0,59 & 0,55 & 0,59 & 0,58 & 0,60 & 0,60 \\
\hline 9. & 0,54 & 0,40 & 0,50 & 0,42 & 0,46 & 0,35 \\
\hline
\end{tabular}

EEÜKAT’nin birinci aşamasının ortalama güçlüğü: 0,66; ikinci aşamasının ortalama güçlüğü: 0,65

Tablo 4 incelendiğinde testte yer alan soruların madde ayırt edicilik indekslerinin birinci aşamada 0,37-0,66 arasında, ikinci aşamada 0,34-0,58 arasında, birinci ve ikinci aşama birlikte iken 0,31-0,60 arasında değiştiği görülmektedir. Bu değerlere bakılarak testteki soruların ayırt edicilik indekslerinin istenilen seviyede olduğu söylenebilir. Ayırtedicilik indeksine göre testten çıkarılmayı gerektirecek herhangi bir madde bulunmamaktadır. Soruların madde güçlük indekslerinin ise birinci aşamada 0,52-0,82 arasında, ikinci aşamada 0,50-0,81 arasında, birinci ve ikinci aşama birlikte iken 
0,46-0,78 arasında değiştiği görülmektedir. Buna göre testteki soruların orta güçü̈kte, hatta bazılarının kolay seviyede oldukları söylenebilir. EEÜKAT'nin güvenirliğine karar vermek için Cronbach's alpha değerine bakılmıştır. Testin birinci aşamasının güvenirlik katsayısı 0,80, ikinci aşamasının güvenirlik katsayısı 0,76 , birinci ve ikinci aşamanın birlikte güvenirlik katsayısı ise 0,75 bulunmuştur. Bu da testin güvenilir olduğunu göstermektedir. Genel olarak bir testin güvenirlik kat sayısının 0,70 ve üzerinde olması, o testin güvenilir bir test olarak kabul edilebilmesi için yeterli olduğu ifade edilmektedir (Büyüköztürk, 2011). Kavramsal anlama testinin analiz sonuçları bilimsel olarak kabul gören değerlere sahip olduğundan testte soru elemeye gidilmemiş, 9 soru ile kavramsal anlama testine nihai hali verilmiştir.

\section{Veri toplama süreci}

Uygulamalara başlamadan önce çalışmanın yapılacağı deney ve kontrol grubundaki öğrencilerin karne notları incelenmiş ve eşit ortalamalara sahip olan iki yedinci sınıftan biri deney, diğeri kontrol grubu olarak rasgele olarak belirlenmiştir. EEÜKAT uygulamalardan önce öğrencilerin konuya ilişkin ön bilgilerinin yoklanması için uygulanmıştır. Daha sonra deney grubuna yedinci sınıf elektrik enerjisi ünitesine yönelik OBYM kapsamında geliştirilen plan ve etkinlikler (Tablo 5, Şekil 1-5); kontrol grubuna ise herhangi bir müdahalede bulunulmadan sadece 2013 Fen Bilimleri Dersi Öğreti Programına göre elektrik enerjisi ünitesiyle ilgili içerik ve kazanımlar uygulanmıştr. Uygulama bittikten sonra daha önce ön-test olarak uygulanan EEÜKAT son-test olarak tekrar uygulanmıştr. Uygulama ön-test ve son-test süreci de dahil olmak üzere 6 hafta sürmüştür. Uygulamanın sonunda deney ve kontrol grubunun ön-test ve son-test puan ortalamaları arasında anlamlı bir fark olup olmadığına bakılmıştır.

\section{Deney Grubunda Derslerin İşlenişi}

Deney grubunda elektrik enerjisi ünitesinin öğretimi araştırmacılar tarafindan hazırlanan OBYM destekli etkinliklerle yürütülmüştür. OBYM, 4 aşamadan oluşmaktadır; (1) keşfetme ve sınıflandırma, (2) yapılandırma ve müzakere etme, (3) transfer etme ve genişletme, (4) yansıtma ve değerlendirme. Öğretim materyalleri hazırlanırken modelin birbirini takip eden bu dört aşaması, her aşamanın amaçları ve de fen bilimleri dersi öğretim programında yer alan kazanımlar dikkate alınmıştır. EEÜKAT hazırlanırken soruların, özellikle yedinci sınıf öğrencilerinin elektrik enerjisi ünite konularını öğrenmede güçlük çektiği kavramlardan, sahip oldukları alternatif kavram veya kavram hatalarını ortaya çıkarabilecek nitelikte olmalarına özen gösterilmiştir. Bundan dolayı da OBYM destekli etkinlikler hazırlanırken bu durum göz önünde bulundurulmuştur. Elektrik enerjisi ünite konuları için benzer işlemler yapıldığından, örnek olması amacıyla "seri ve paralel bağlama" konusuna ait örnek bir ders planı Tablo 5'te sunulmuştur. Uygulamanın diğer haftalarında da benzer işlemler yapılmıştır. OBYM'nin aşamalarına göre konular hazırlanan bu etkinliklerle deney grubu öğrencilerine öğretilmiştir. Örneğin adı geçen ünitenin konularından biri "akım ve gerilim" dir. Bu konu, OBYM'nin birinci evresi olan keşfetme ve sınıflandırmaya göre planlanmış ve "önlemini al, hayatta kal" çalışma yaprağı hazırlanmıştır (Şekil 1). Bu evrede amaç, birkaç basit etkinlik yardımıyla öğrencilerin konuya ilişkin ön bilgilerini açığa çıkarmak ve öğrencilerin ifadelerindeki ortak noktalara göre kategoriler oluşturmaktır. Öğretmen bu aşamada öğrencilerin görüşlerini kesinlikle doğru-yanlış olarak değerlendirmemelidir. Öğrencilerin neyi ne kadar bildiğine değil, neyi nasıl düşündüğüne odaklanmalı, öğrencilerin görüşlerini özgürce açığa çıkarmaları için destekleyici bir ortam yaratmalıdır. Öğrencilere verilen bu çalışma yaprağından sonra, "hiç düşündünüz mü?" ve "leyden şişesi" çalışma yaprakları verilmiş ve istenilenler doğrultusunda öğrenciler yönlendirilmiştir. OBYM’nin ikinci aşaması olan yapılandırma ve müzakere etme evresidir. Bu evrede, bilimsel bilgiyi yapılandırma ve kavramların anlamını müzakere etme vardır. Öğretmen-öğrenci(ler) ve öğrenci-öğrenci etkileşiminin gerçekleşmesi oldukça önemlidir. Öğrenciler bilimsel bilginin sadece gözlem, deneysel kanıt, rasyonel argümanlar ya da şüpheciliğe dayanmadığını günlük hayatla ilişkili sorular sorduklarında, fikirlerini eleştirel düşünmeye açtıklarında, çevresindekilerle müzakere ettiklerinde kavramları daha iyi öğrenebileceklerini fark edeceklerdir. Bu evrede ilk olarak öğrencilere "titreşelim enerjiyi aktaralım" çalışma yaprağı verilmiş (Şekil 2) ve istenilenler doğrultusunda yönlendirilmişlerdir. Bu evrede gruplandırma önemlidir. Bundan dolayı da öğrenciler gruplara ayrılmış ve etkinlikler yapılmıştır. İlk etkinliği ardından, "sizce kim hakı”, "siz ne düşünüyorsunuz?" ve "enerjimiz farklı" etkinlikleri yapılarak bu aşama bitirilmiştir.

\section{Tablo 5. OBYM'ye göre hazırlanmış ders planı örneği}

\begin{tabular}{ll}
\hline BÖLÜM-I & \\
\hline Dersin Adı & Fen Bilimleri \\
Sınıf/Şube & 7/A \\
Ünitenin Adı & Elektrik Enerjisi \\
Konu & Seri ve Paralel Bağlama \\
Önerilen Süre & 8 ders saati (320 dakika) \\
Öğrenci Kazanımları & Seri ve paralel bağlamanın nasıl olduğunu keşfeder, seri ve paralel bağlı ampullerden oluşan bir \\
& devre şeması çizer
\end{tabular}


Ampullerin seri ve paralel bağlandığı durumlardaki parlaklık farklılıklarını devre üzerinde gözlemler ve sonucunu yorumlar.

Ampullerin seri ve paralel bağlandığı durumlardaki parlaklık farklılığının sebebini elektriksel dirençle ilişkilendirir.

Anahtar Kavramlar Öğrenme-Öğretme tem ve Teknikleri

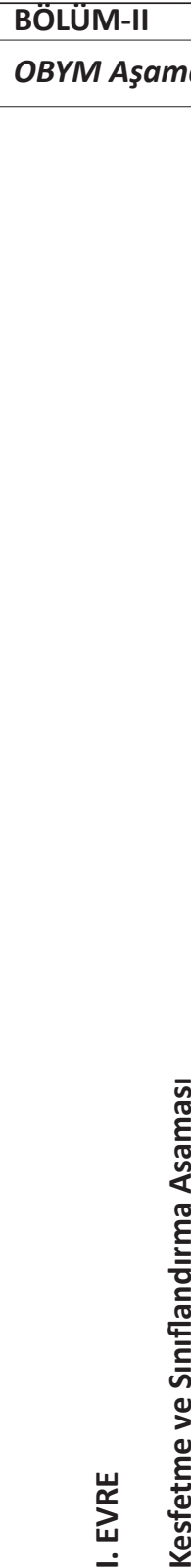

Seri Bağlama, Paralel Bağlama, Toplam Direnç (Eşdeğer Direnç)

Yön- İşbirliğine Dayalı Öğrenme, Beyin Fırtınası, Sınıf Tartışması, TAGA (Tahmin Açıkla Gözlem Açıkla), Kavramsal Değişim Metinleri, Kavram Karikatürü, Çalışma Yaprakları
Öğrencilerin tek kablodan ve iki kablodan oluşan basit bir elektrik devresinin kurulmasıyla ilgili ön bilgilerini keşfetmek için hazırladığı "Tom ve Jerry devre kuruyor" çalışma yaprağını öğrencilere dağıtır. Dağıtthğı çalışma yaprağı hakkında öğrencileri bilgilendirir ve doldurmaları için belli bir süre tanır.

Öğrencilerden çalışma yapraklarını toplayarak değerlendirir. Öğrenci fikirlerini sınıflandırır.

Oluşan kategorilere göre öğrencileri gruplara böler ve konu hakkında sınıf tartışması başlatır. Bu tartışmalara rehberlik eder.

Ardından, öğrencilerin ampullerin bağlanma şekilleriyle ilgili ön bilgilerini keşfetmek için "ampulleri nasıl bağlayaIım?" adlı çalışma yaprağını dağıtır.

Bir önceki çalışma yaprağında izlediği adımları burada da izler.

Not: Bu evrede öğretmen, öğrencilerin fikirlerini kesinlikle doğru, yanlış olarak değerlendirmez, her öğrencinin görüşünü rahatça ifade edebileceği bir ortam sağlar.

"trafik lambasının icadı" adlı etkinliği sınıfa dağıtır ve gönüllü iki öğrenciden konuşma metinlerini okumalarını ister.

Öğrencilerin soruları bireysel olarak cevaplandırmaları için belli bir süre tanır. Ardından soruların sınıfça tartışılmasına rehberlik eder.

Bilimin doğasının "deneysellik, hayal gücü ve yaratıcılık" gibi boyutları hakkında öğrencilerde farkındalık oluşturur.

\section{Öğrencinin Rolü}

Öğrenciler kendilerine verilen "Tom ve Jerry devre kuruyor" etkinliğinde, kendilerine resmi verilen devre malzemelerini kullanarak ayrı ayrı tek kablolu ve iki kablolu basit bir elektrik devresinin nasıl kurulacağını önce yazarak, sonra çizerek açıklar.

Öğrenciler, görüşleri öğretmen tarafından değerlendirilip sınıflandırılıncaya kadar kendi aralarında görüşlerini paylaşırlar.

Öğrenciler konu hakkındaki düşüncelerini sınıfla paylaşırlar. Düşüncelerini savunurlar ve tartışırlar.

Öğrenciler, bir önceki çalışma yaprağında izlediği adımları, "ampulleri nasıl bağlayalım?" adlı çalışma yaprağı için de uygular.

Öğrenciler, bir önceki çalışma yaprağında izlediği adımları bu etkinlikte de tekrarlar.

"trafik lambasının icadı" etkinliğindeki konuşma metinlerini gönüllü iki öğrenci okur.

Metinlere ait soruları önce her öğrenci bireysel olarak cevaplandırır. Ardından sorular tüm sınıfın katılımıyla tartışılır.

Bilimin doğasının bazı unsurlarından haberdar olurlar. 
“elektrikler mi kesildi?” etkinliği gruplara dağıtır. Gruplara, etkinliğin giriş kısmı$\mathrm{n}$ incelemeleri ve görüşlerini yazmaları için yeteri kadar süre tanır.

Sonra, gönüllü öğrencilere etkinliğin giriş kısmındaki konuşma baloncuklarını okutur.

Etkinlikte yer alan sorularla ilgili her grubun görüşünü açıklamasını ister. Ardından konuyla ilgili sınıf tartışması başlatarak rehberlik eder.

Sınıf tartı̧̧masının ardından 3 tane seri bağlı ampulden oluşan devreyle ilgili TAGA tekniğini uygular (Gruplardan devreyle ilgili sorulan soru hakkında tahminlerini ve tahminlerinin sebeplerini tabloya yazmalarını ister. Ardından grupların bu devreyi kurarak gözlem yapmalarını ve gözlem sonuçlarını tabloya yazmaları$\mathrm{n}$ ı ister). Son olarak her grubun gözlem sonuçlarını sınıfla paylaşmalarını, tahminleriyle gözlemlerinin uyuşup uyuşmadığını açıklamalarını ister.

Etkinliğin devamında yer alan sorular hakkında sınıf tartışması yürütür ve rehberlik eder.

TAGA tekniğine göre hazırlanmış olan "ampulleri seri ve paralel bağlayalım" etkinliğini gruplara dağıttr. Bir önceki etkinlikte olduğu gibi, grupların bu etkinliği de TAGA'ya uygun adımları izleyerek yürütmelerine rehberlik eder.

Etkinlik tamamlandığında seri ve paralel bağlamanın avantaj ve dezavantajları hakkında grupların kendi aralarında fikir alışverişi yapmalarını sağlar. Ardından konuyla ilgili sınıf tartışması başlatır ve buna rehberlik eder. Bu konuyla ilgili bir sonraki derse poster hazırlayarak gelmeleri konusunda öğrencileri teşvik eder. Seri bağlı ampullerin parlaklığı ile ilgili "sizce kim haklı?" etkinliğini gruplara dağıttr. Orada yazan görüşleri okuduktan sonra bu görüşler üzerine tartş̧malarını sağlar.

"siz ne düşünüyorsunuz?" kavramsal değişim metnini gruplara dağıttr ve sessizce okumalarını ister.

Grupların okumaları bittiğinde, her bir alternatif fikri istekli bir öğrenciye sesli olarak okutup üzerinde sınıf tartı̧̧ması yaptırır. Böylece bilimsel olarak doğru olmayan görüşlerin, bilimsel doğrularla yer değiştirmesini sağlar.
Her grup "elektrikler mi kesildi?" etkinliğinin giriş kısmını inceleyip ortak görüşlerini yazarlar.

Gönüllü öğrenciler konuşma balonlarındaki yazıları okurlar.

Gruplar görüşlerini sınıfla paylaşırlar ve konuyu tartişırlar.

Gruplar öncelikle şekli verilen devreyi dikkatlice inceler ve sorulan soru hakkında aralarında görüş alış verişinde bulunurlar. Sonra soru ile ilgili tahminlerini ortak karar alarak tabloya yazarlar ve niçin böyle düşündüklerini açıklarlar. Daha sonra gruplar şekli verilen elektrik devresini kurar ve gözlem yaparlar. Gözlem sonuçlarını tabloya kaydederler. Her grup gözlem sonuçlarını sınıfla paylaşır, tahminleri ile gözlemlerinin uyuşup uyuşmadığı üzerine tartışma yürütürler.

Etkinliğin devamında yer alan sorular hakkındaki görüşlerini belirtip tartşırlar.

"ampulleri seri ve paralel bağlayalım" etkinliğinde, bir önceki etkinlikte olduğu gibi TAGA'ya uygun adımları izlerler.

Seri ve paralel bağlamanın avantajları ve dezavantajları hakkında önce gruplar kendi içlerinde fikir alışverişinde bulunurlar. Sonra her grup, görüşlerini sınıfla paylaşır. Konu hakkındaki görüşlerini savunur ve tartişırlar.

Seri bağı ampullerin parlaklığı ile ilgili kendilerine dağıtılan "sizce kim haklı?” etkinliğindeki görüşleri okurlar ve sınıfça yürütülen tartışmaya katılırlar.

Gruplar kendilerine dağıttlan "siz ne düşünüyorsunuz?" kavramsal değişim metnini sessizce okurlar.

Ardından her bir alternatif fikri gönüllü bir öğrenci sesli okur ve her bir alternatif kavram üzerinde sınıfça tartışırlar. Böylece seri ve paralel bağlı devrelerde, devrenin toplam direnci, ampul parlaklığı gibi faktörlerin nasıl değiştiği hakkında eksik ya da yanlış anlamalarını giderirler. 
“bütün ışıklar neden söndü?" adlı etkinlik öğrencilere dağıtılır. Sessizce okuyup soruları cevaplandırmalarını ister.

Ardından gönüllü öğrencilere örnek olayları okutur ve soru üzerinde tartı̧̧ma yürüterek rehberlik eder.

"trafik lambası yapalım" adlı kavramsal karikatürü öğrencilere dağıttr ve incelemelerini ister. Yönergelere uygun olarak devreyi çizmelerini ve görüşlerini yazmalarını ister.

Öğrenciler görüşlerini yazıp çizdikten sonra sınıf tartş̧ması başlatır ve buna rehberlik eder.

"Edison ampulü nasıl icat etmiştir?" adlı etkinliği sınıfa dağıttr ve gönüllü bir öğrenciden parçayı okumasını ister.

Parçadaki soruları her öğrencinin bireysel olarak cevaplandırmasını ister. Ardın-

(]) dan, başlattı̆̆ sınıf tartışmasına rehberlik eder.

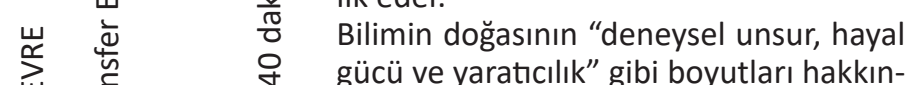

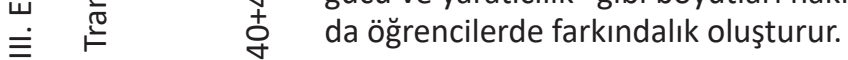

守 Öğrencilere "neler öğrendik?" adlı ölçme aracını dağıtır. Her öğrencinin öncelikle bireysel olarak cevaplandırabilmesi için yeteri kadar süre tanır.

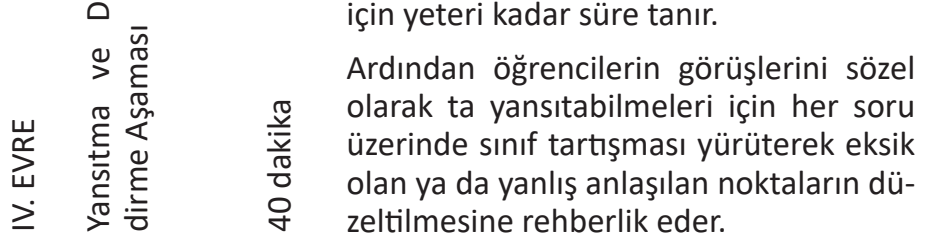

ÖNLEMINI AL, HAYATTA KAL!
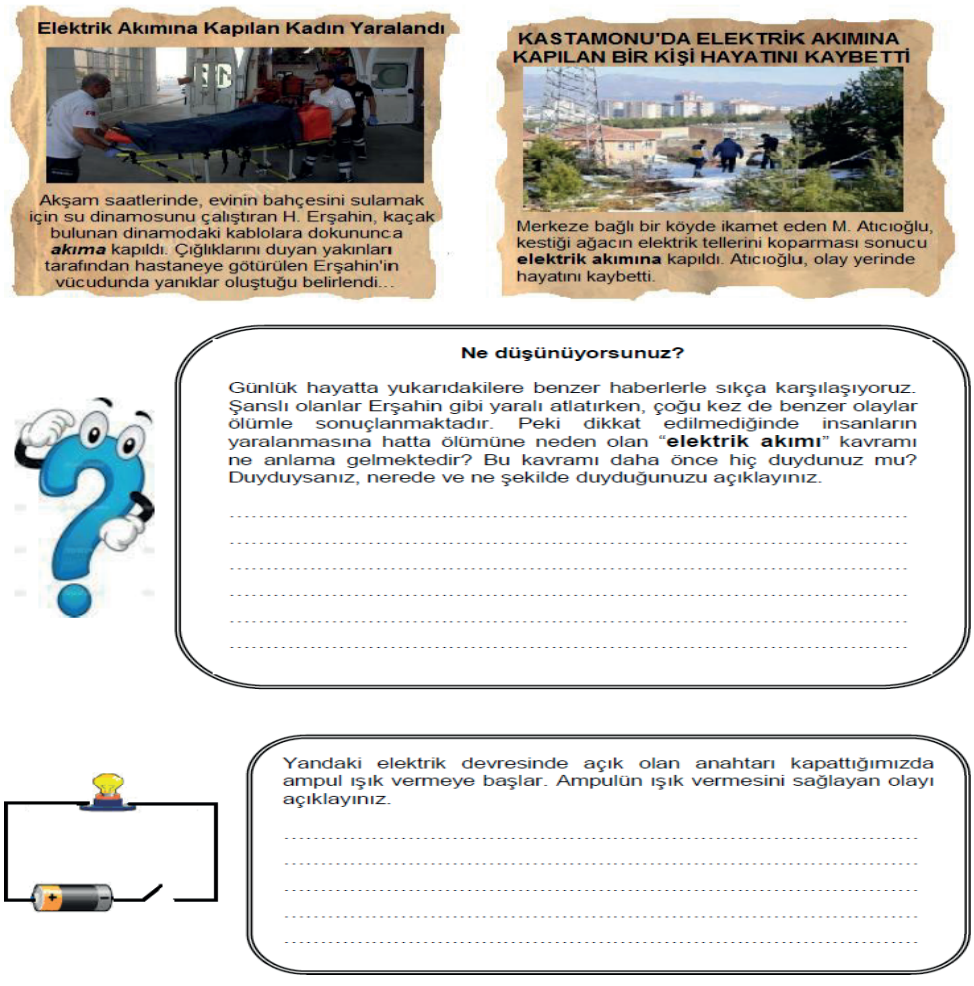

\section{Şekil 1. Keşfetme ve sınıflandırmaya örnek etkinlik}

OBYM'nin üçüncü aşaması transfer etme ve genişletme evresidir. Bu evrede, öğrencilere öğrendiklerini günlük ya-
Her öğrenci "bütün ışıklar neden söndü?" adlı etkinliği bireysel olarak okur ve soru hakkındaki düşüncelerini kağıda yazar.

Gönüllü öğrenciler verilen örnek olayları okur.

Öğrenciler soruyla ilgili yürütülen sınıf tartışmasına katılırlar.

Öğrenciler "trafik lambası yapalım" adlı kavramsal karikatürü inceleyip, yönergelere uygun olarak devreleri çizerler ve görüşlerini yazarlar.

Öğretmenin başlattığı sınıf tartışmasına katılırlar.

"Edison ampulü nasıl icat etmiştir?" etkinliğindeki parçayı gönüllü bir öğrenci okur.

Parçaya ait soruları önce her öğrenci bireysel olarak cevaplandırır, ardından her soru tüm sınıf tarafindan tartışılır.

Bilimin doğası hakkında fikir sahibi olurlar.

Her öğrenci "neler öğrendik?" adlı ölçme aracını bireysel olarak cevaplandırır.

Ardından yürütülen sınıf tartışmasına katılarak görüşlerini yansıtır. Böylece, hem yanlış ya da eksik öğrendiği konuları fark eder hem de öğrendiklerini pekiştirir. 
şamla ilişkilendirmesi için çok sayıda firsat verilir. Böylece yapılandırdıkları görüşlerini başka disiplinlere ya da sosyal konulara aktarma ve genişletme firsat edinirler. Öğrenci, bu aşamada, bir önceki aşamada öğrendiklerini sosyobilimsel problemlerde kullanmaktadır. Bu amaç doğrultusunda ilk etkinlik, "kuşları neden elektrik çarpmaz?” (Şekil 3). Bu etkinliğin ardından öğrencilere "Kastamonu'da büyük yangın” ve "pilin icadı" gibi çalışma yaprakları verilerek gerekli etkinlikleri yapmaları sağlanmıştır. OBYM'nin son aşaması yansıtma ve değerlendirme evresidir. Bu evrede, alternatif ölçme ve değerlendirme ön plandadır. Burada daha çok öğrencinin neyi-nasıl öğrendiğiyle ilgilenilmekte, sadece sonuç değil süreç te değerlendirilmektedir. Bu modele göre değerlendirme sadece öğretim sürecinin sonunda yapılmamalı, öğrencilerin düşüncelerini açığa çıkarmak, öğretimin ne kadar etkili olduğuna karar vermek, hangi kavramların tekrar değerlendirilmesi gerektiğini ortaya çıkarmak için yapılmalıdır. Bu evrede öğrencilere "neler öğrendik" çalışma yaprağı verilmiş ve gerekli etkinlikler yapılmıştır (Şekil 4). Diğer konu başlıkları da benzer şekilde planlanmış ve 6 hafta boyunca benzer şekilde deney grubu öğrencilerine ilgili ünite konuları anlatılmıştır. Ayrıca deney grubu öğrencileriyle beraber yapılan uygulamalardan bazı örnekler Şekil 5'te gösterilmiştir.

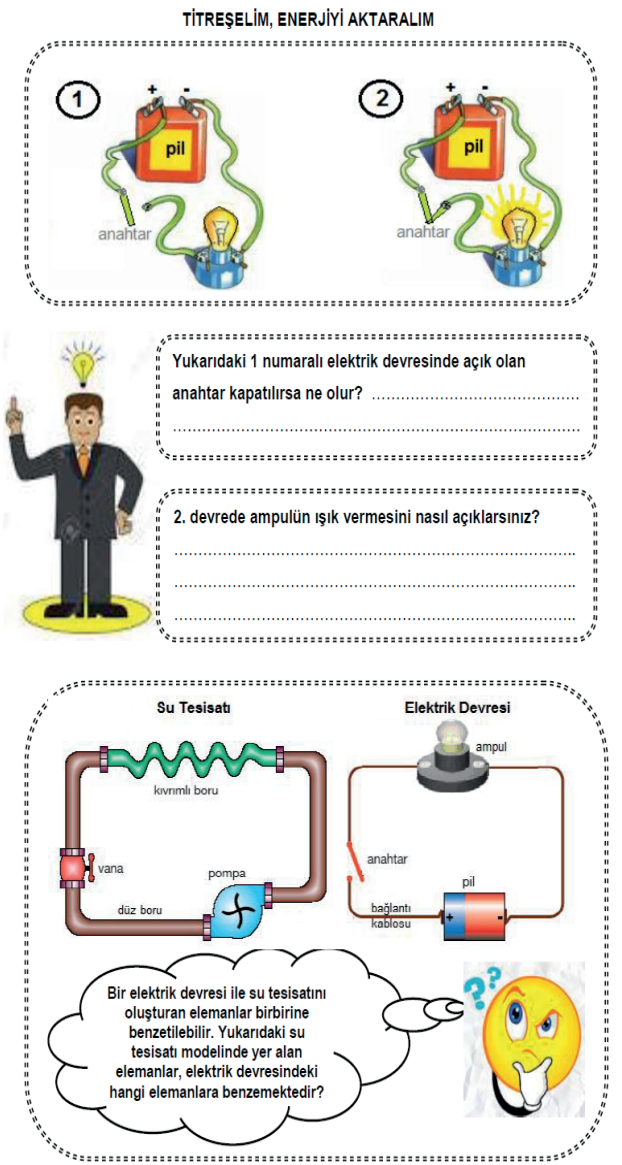

Şekil 2. Yapılandırma ve müzakere etme örnek etkinlik

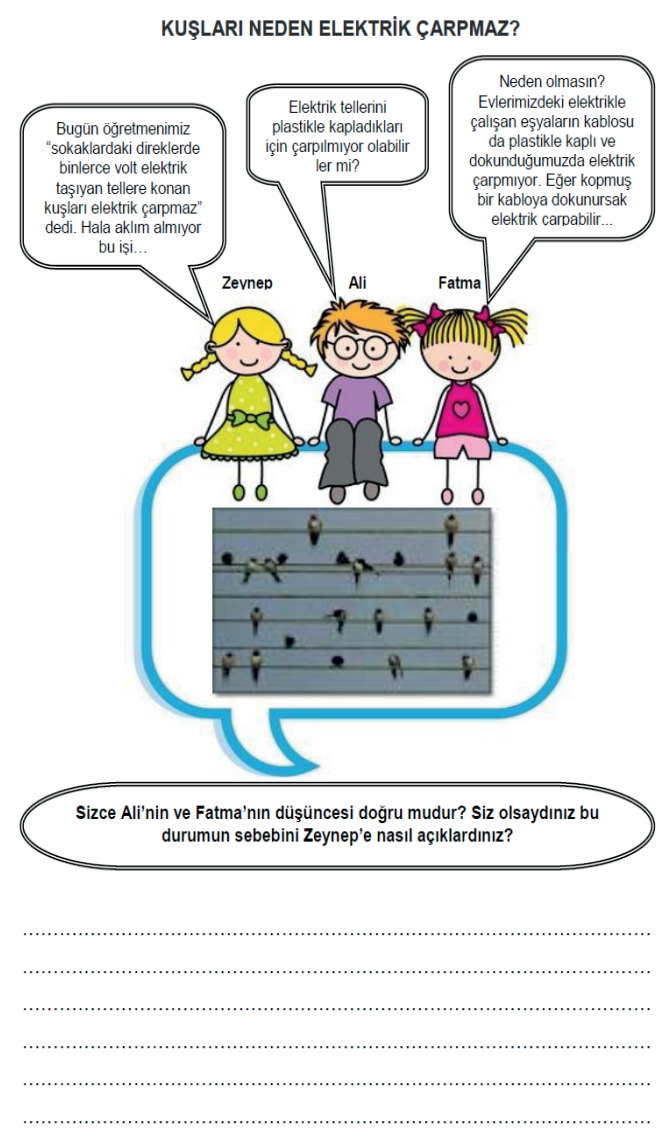

Şekil 3. Transfer etme ve genişletme örnek etkinlik 


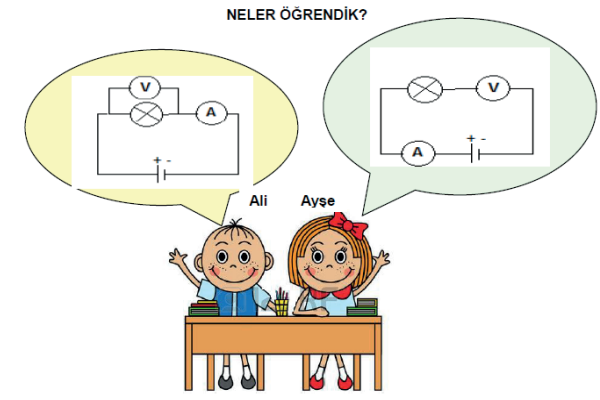

Ali ve Ayşe ampermetre ve voltmetreyi
kimin kurduğu devre hatalılır? Neden?

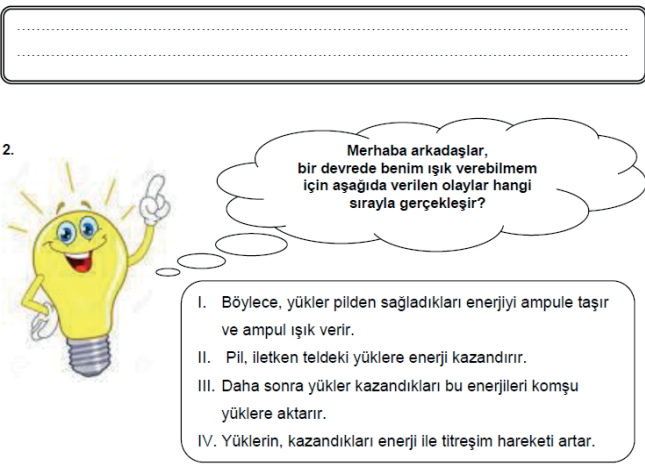

Siralama

Şekil 4. Yansıtma ve değerlendirme örnek etkinlik
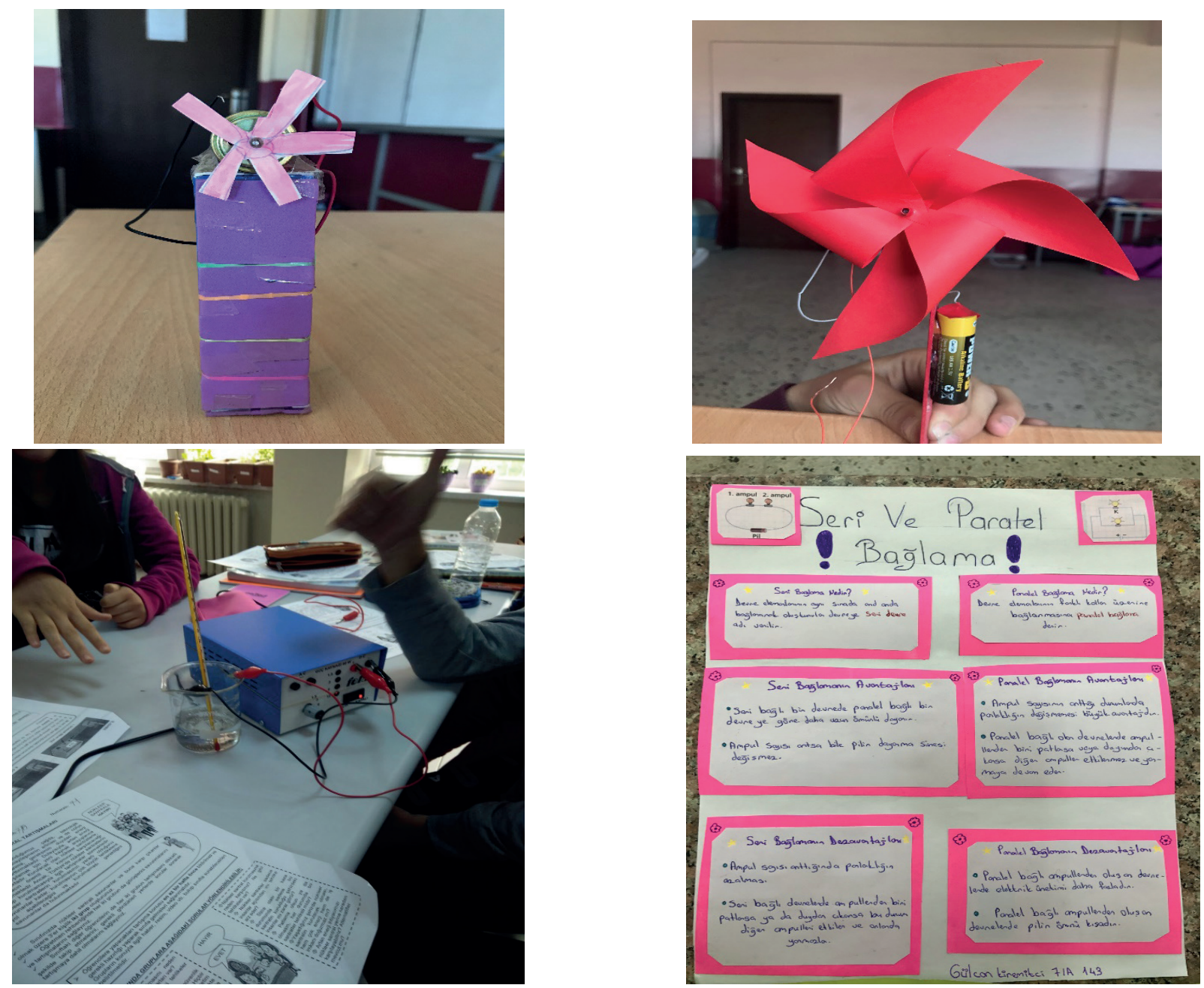

Şekil 5. Deney grubunda yapılan etkinliklerden bazı örnekler

| Kastamonu Eğitim Dergisi, 27(5), 2019| 


\section{Verilerin Analizi}

Bu bölümde, araştırmanın verilerinin çözümlenmesi ve yorumlanmasına ilişkin süreçler ve bu süreçlerde kullanılan analiz yöntemleri yer almaktadır. Elektrik Enerjisi Ünitesi Kavramsal Anlama Testi (EEÜKAT), iki aşamalı ve çoktan seçmeli 9 sorudan oluşmaktadır. Her sorunun birinci aşaması biri doğru cevap diğer ikisi çeldirici olmak üzere üç seçenek içermektedir. Soruların ikinci aşamasında ise, birinci aşamada verilen cevabın nedenini içeren üç seçenek yer almaktadır. Testteki her sorunun iki aşamasını da doğru yanıtlayan öğrenciler o sorudan 1 puan alırken, sorunun birinci veya ikinci aşamasını yanlış işaretleyen ya da boş bırakan öğrenciler o sorudan sıfir puan almıştr. Böylece, kavramsal anlama testinden alınabilecek maksimum puan 9 iken, minimum puan ise 0 dır. EEÜKAT her iki grupta ön-test ve son-test olarak uygulanmıştir.

Verilerin analizinde SPSS programından yararlanılmıştı. Ayrıca, bir araştırmada elde edilen verilerin normal bir dağılım gösterip göstermediğinin belirlenmesinde gözlem sayısının 35'den büyük olması durumunda Kolmogorov Smirnov testi (McKillup, 2012), küçük olması durumunda ise Shapiro-Wilk testi (Shapiro ve Wilk, 1965) kullanılmaktadır. Bu çalışmada, EEÜKAT'den elde edilen verilerin normal dağıııma uygun olup olmadığını belirlemek için normallik testi yapılmış olup örneklem büyüklüğü 35'den küçük olduğu için Shapiro-Wilk test sonuçları değerlendirilmiş ve $p>, 05$ olduğundan normal dağılım gösterdiği için t-testinin kullanılmasına karar verilmiştir.

\section{Bulgular ve Yorumlar}

OBYM'nin fen bilimleri dersi elektrik enerjisi ünite konularının öğretiminde kullanılmasının yedinci sınıf öğrencilerinin kavramsal anlamaları üzerindeki etkilerinin araştııldığı bu araştırmada elde edilen verilerin bulguları her bir alt probleme göre açıklanmış ve tablolar halinde aşağıda verilmiştir.

Birinci alt problem: Deney ve kontrol grubu öğrencilerinin uygulama öncesinde EEÜKAT puan ortalamaları arasında anlamlı bir fark var mıdır? Bu probleme yönelik deney ve kontrol gruplarından elde edilen verilerin analizinde bağımsız örneklemler için t-testi kullanılmıştır ve verilere ait tanımlayıcı istatistikler Tablo 6'da gösterilmiştir.

Tablo 6. Deney ve kontrol grubu öğrencilerinin uygulama öncesi EEÜKAT ön-test verileri

\begin{tabular}{lccccc}
\hline Grup & $\mathbf{N}$ & $\overline{\mathbf{X}}$ & SS & $\mathbf{t}$ & $\mathbf{p}$ \\
\cline { 1 - 4 } Deney grubu ön-test & 22 & 2,81 & 1,22 & & \\
\cline { 1 - 4 } Kontrol grubu ön-test & 20 & 2,70 & 1,38 & &
\end{tabular}

${ }^{*} p>, 05$

Tablo 6 incelendiğinde deney grubu öğrencilerinin EEÜKAT ön-test puan ortalaması $\overline{\mathrm{X}}=2,81$ ve standart sapması 1,22 olduğu görülmektedir. Kontrol grubu EEÜKAT ön-test puan ortalaması $\bar{X}=2,70$ ve standart sapması $1,38^{\prime}$ dir. Deney ve kontrol grubu EEÜKAT ön-test verilerine göre iki grup arasında anlamlı bir fark olmadığı görülmektedir ( $\mathrm{t}=0,295$; $p>, 05)$. Uygulama öncesinde iki grubun da fen bilimleri dersine yönelik kavramsal anlamaları birbirine denktir.

İkinci alt problem: Deney ve kontrol grubu öğrencilerinin uygulama sonunda EEÜKAT puan ortalamaları arasında anlamlı bir fark var mıdır? Deney ve kontrol grupları EEÜKAT son-test verileri bağımsız örneklemler t-testi ile analiz edilmiş ve son-test puan ortalamaları, standart sapmaları, p ve t değerleri Tablo 7'de verilmiştir.

Tablo 7. Deney ve kontrol grubu öğrencilerinin uygulama sonrası EEÜKAT son-test verileri

\begin{tabular}{lccccc}
\hline Grup & $\mathbf{N}$ & $\overline{\mathbf{X}}$ & $\mathbf{S S}$ & $\mathbf{t}$ & $\mathbf{p}$ \\
\hline Deney grubu son-test & 22 & 6,0 & 1,95 & & \\
\cline { 1 - 4 } Kontrol grubu son-test & 20 & 4,1 & 2,22 & & \\
\cline { 1 - 4 } & & & & & \\
\hline
\end{tabular}

$*_{p<, 05}$

Tablo 7'ye göre deney grubu öğrencilerinin EEÜKAT son-test puan ortalaması $\bar{X}=6,0$ ve standart sapması 1,95; kontrol grubu öğrencilerinin EEÜKAT son-test puan ortalaması $\bar{X}=4,1$ ve standart sapması 2,22'dir. Deney ve kontrol grubunun son-test puan ortalamaları arasında istatistiksel olarak anlamlı bir fark görülmektedir $(t=2,950 ; p<, 05)$. Sonuç olarak, OBYM ile derslerin işlendiği deney grubundaki öğrencilerin kavramsal anlamaları, 2013 Fen Bilimleri Dersi Öğretim Programına göre derslerin işlendiği kontrol grubundaki öğrencilerin kavramsal anlamalarından daha yüksek çıkmıştır.

Üçüncü alt problem: Deney grubu öğrencilerinin uygulama öncesi ve sonrasında EEÜKAT puan ortalamaları arasında anlamlı bir fark var mıdır? Deney grubunun ön-test ve son-test verilerinin analizinde bağımlı örneklemler için t-testi 
kullanılmıştır. Verilere ait tanımlayıcı istatistikler Tablo 8'de gösterilmiştir.

Tablo 8. Deney grubu öğrencilerinin uygulama öncesi ve sonrası EEÜKAT ön-test son-test verileri

\begin{tabular}{lccccc}
\hline Grup & $\mathbf{N}$ & $\overline{\mathbf{X}}$ & $\mathbf{S S}$ & $\mathbf{t}$ & $\mathbf{p}$ \\
\cline { 1 - 4 } Deney grubu ön-test & 22 & 2,8 & 1,22 & & \\
\cline { 1 - 3 } Deney grubu son-test & 22 & 6,0 & 1,95 & $-6,31$ &, $000 *$ \\
\hline
\end{tabular}

${ }^{*} p<, 05$

Tablo 8 incelendiğinde, deney grubu öğrencilerinin EEÜKAT ön-test puan ortalaması $\bar{X}=2,8$ ve standart sapması 1,22; son-test puan ortalaması $\bar{X}=6,0$ ve standart sapması 1,95 olduğu görülmektedir. Buna göre deney grubunda uygulama öncesi ve sonrasında uygulanan EEÜKAT puan ortalamalarının arasında anlamlı bir fark vardır $(\mathrm{t}=-6,31 ; p<, 05)$. Buna göre OBYM destekli öğretim deney grubu öğrencilerinin kavramsal anlamalarını artırmıştr. Elektrik enerjisi ünitesine yönelik hazırlanan EEÜKAT, deney ve kontrol grubu öğrencilerine ön-test ve son-test olarak uygulanmış, elde edilen bulgular her bir soru için ayrı ayrı analiz edilerek frekans ve yüzde değerleri hesaplanarak Tablo 9'da gösterilmiştir.

Tablo 9. Soruların Doğru cevaplanma frekansları ve yüzdeleri

\begin{tabular}{lcccccccc}
\hline & \multicolumn{4}{c}{ Deney Grubu } & \multicolumn{5}{c}{ Kontrol Grubu } \\
Soru & \multicolumn{2}{c}{ Ön-test } & \multicolumn{2}{c}{ Son-test } & \multicolumn{2}{c}{ Ön-test } & Son-test \\
\cline { 2 - 10 } & $f$ & $\%$ & $f$ & $\%$ & $f$ & $\%$ & $f$ & $\%$ \\
\hline 1. & 14 & 63,6 & 20 & 91,0 & 12 & 60 & 14 & 70 \\
2. & 8 & 36,4 & 18 & 81,8 & 7 & 35 & 9 & 45 \\
3. & 8 & 36,4 & 19 & 86,4 & 11 & 55 & 11 & 55 \\
4. & 12 & 54,6 & 12 & 54,6 & 5 & 25 & 4 & 20 \\
5. & 3 & 13,6 & 14 & 63,6 & 1 & 5 & 7 & 35 \\
6. & 8 & 36,4 & 20 & 91,0 & 11 & 55 & 14 & 70 \\
7. & 2 & 9,1 & 12 & 54,6 & 2 & 10 & 10 & 50 \\
8. & 1 & 4,5 & 12 & 54,6 & 3 & 15 & 5 & 25 \\
9. & 6 & 27,3 & 9 & 40,9 & 2 & 10 & 8 & 40 \\
\hline
\end{tabular}

1. Soru: Aşağıdaki şekillerin hangisinde ampul ışık verir?

A)

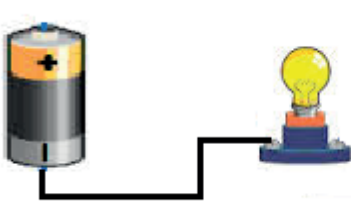

B)

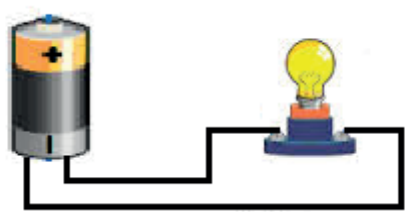

C)

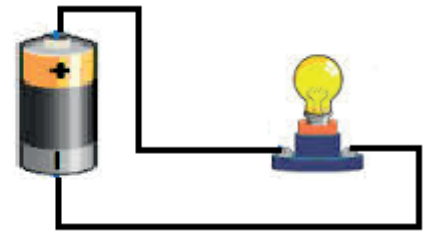

(Tek kutuplu model: Öğrenci ampulün yanabilmesi için, ampul ile pil arasında tek bir kablo bağlantısının yeterli olduğunu düşünmektedir).

Çünkü;

a) Ampul ile pilin herhangi bir kutbu arasında tek bir kablo bağlantısı yeterlidir.

b) Ampul ile pilin herhangi bir kutbuna bağı iki kablo bağlantısı yeterlidir.

c) Ampul ile pilin her iki kutbuna da bağlı iki kablo bağlantısı gereklidir.

Birinci sorunun analizinde; deney grubu öğrencilerinin \%63,6'sı, kontrol grubu öğrencilerinin ise de \%60' ön-testin her iki aşamasında da doğru seçeneği işaretlemişlerdir. Son-testte ise her iki aşamayı da doğru cevaplayanların oranı deney grubunda \%91'e, kontrol grubunda ise \%70'e çıkmıştı. Alternatif kavram içeren seçeneklerin işaretlenme oranı her iki grupta da azalmıştr. 
2. Soru: Aşağıdaki elektrik devresinde ampul yanmaktadır. Ampulden geçen akım ve ampulün yanmasını açıklayan ifade hangisidir?

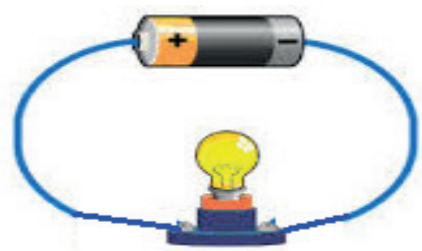

(Çarpışan akımlar modeli: Öğrenci, pilin (+) ve (-) ucundan çıkan elektrik akımının, ampulde çarpışarak ampulün yanmasını sağladığını düşünmektedir).

A) Akım, pilin (+) kutbundan (-) kutbuna gider ve ampul yanar

B)Akım, pilin (-) kutbundan (+) kutbuna gider ve ampul yanar

C) Akım, pilin her iki kutbundan da çıkar ve ampul yanar

Çünkü;

a) Pilin (+) ucundan gelen akım ile pilin (-) ucundan gelen akım, ampulün içinde karşılaşıp çarpışır ve ampul yanar.

b) Pilden enerji alarak pilin (-) ucundan itibaren titreşim hareketi yapan yükler, pilin (+) ucuna varır ve ampul yanar.

c) Pilin (+) ucundan gelen akım, ampulün üzerinden geçip pilin (-) ucuna ulaşır ve ampul yanar.

d) ......

İkinci sorunun analizinde; deney grubu öğrencilerinin \%36,4'ü, kontrol grubu öğrencilerinin de \%35'i ön-testin her iki aşamasında da doğru seçeneği işaretlemişlerdir. Son-testte ise her iki aşamayı da doğru cevaplayanların oranı deney grubunda \%81,8'e, kontrol grubunda ise \%45'e çıkmıştır. Her iki grupta da aynı alternatif kavramın çoğunlukla işaretlendiği dikkat çekmektedir. Testin birinci aşamasında yer alan "akım, pilin her iki kutbundan da çıkar ve ampul yanar" ve ikinci aşamada gerekçe olarak sunulan "pilin (+) ucundan gelen akım ile pilin (-) ucundan gelen akım, ampulün içinde karşılaşıp çarpışır ve ampul yanar" alternatif görüşü, ön-testte bütün gruplarda en büyük oranda cevaplanmıştı. Son-testte bu alternatif fikir (çarpışan akımlar modeli) deney grubunda büyük oranda azalırken, kontrol grubunda daha da artmıştir.

3. Soru: Aşağıdaki elektrik devresinde A ve B ampulleri özdeştir ve her iki ampulde yanmaktadır. Buna göre devrede $A$ ampulünden geçen akım miktarı ile $B$ ampulünden geçen akım miktarı arasındaki ilişki hakkında aşağıdaki açıklamalardan hangisi doğrudur?

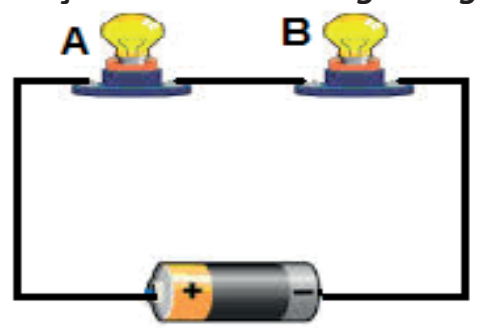

(Zayıflayan akım modeli: Öğrenci, akımın devrede bir yönde ilerlediğini ve üzerinden geçtiği her devre elemanından (ampulden) sonra bir miktar azaldığını düşünmektedir).
A) $A>B$
B) $B>A$
C) $A=B$

Çünkü;

a) A ampulü, üzerinden geçen akımın bir kısmını tüketir ve $B$ ampulünden daha az akım geçer.

b) $B$ ampulü, üzerinden geçen akımın bir kısmını tüketir ve $A$ ampulünden daha az akım geçer.

c) A ampulü üzerinden geçen akımı tüketmediği için A ve B ampullerinden eşit miktarda akım geçer.

Üçüncü sorunun analizinde; deney grubu öğrencilerinin \%36,4'ü, kontrol grubu öğrencilerinin de \%55'i ön-testin her iki aşamasında da doğru seçeneği işaretlemişlerdir. Son-testte ise her iki aşamayı da doğru cevaplayanların oranı deney grubunda \%86,4'e çıkarken, kontrol grubunda ise aynı (\%55) kalmıştır. Testin birinci aşamasında yer alan " $A>B$ " ve ikinci aşamada gerekçe olarak sunulan " $A$ ampulü, üzerinden geçen akımın bir kısmını tüketir ve $B$ ampulünden daha az akım geçer" alternatif görüşü, ön-testte her iki grupta en fazla oranda cevaplanmıştı. Son-testte bu alternatif fikir (zayıflayan akım modeli) deney grubunda büyük oranda azalırken, kontrol grubunda daha da artmıştır. 
4. Soru: Özdeş ampullerle kurulan aşağıdaki elektrik devresinde ampullerin parlaklıkları arasındaki ilişki nasıldır? (Paylaşılan akım modeli: Öğrenci, devrenin şekline (ampullerin paralel ya da seri bağlı olma durumuna) bakmadan, akımın devre elemanları tarafından eşit paylaşıldığını düşünmektedir).

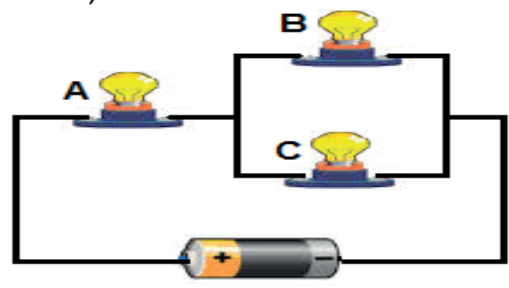
A) $A>B=C$
B) $\mathrm{B}=\mathrm{C}>\mathrm{A}$
C) $A=B=C$

Çünkü;

a) $B$ ve $C$ ampulleri üzerinden geçen akımlar eşit ve $A^{\prime}$ dan büyüktür.

b) $B$ ve $C$ ampulleri üzerinden geçen akımlar eşit ve $A^{\prime}$ dan küçüktür.

c) $A$, $B$ ve $C$ ampullerinden geçen akımlar eşittir.

d)

Dördüncü sorunun analizinde; deney grubu öğrencilerinin \%54,6'sı, kontrol grubu öğrencilerinin de \%25'i ön-testin her iki aşamasında da doğru seçeneği işaretlemişlerdir. Son-testte ise her iki aşamayı da doğru cevaplayanların oranı deney grubunda aynı $(\% 54,6)$ kalırken, kontrol grubunda ise \%20'ye düşmüştür. Testin birinci aşamasında yer alan " $A=B=C$ " ve ikinci aşamada gerekçe olarak sunulan " $A, B$ ve $C$ ampullerinden geçen akımlar eşittir" alternatif görüşü, ön testte bütün gruplarda oranı en çok olandır. Son-testte bu alternatif fikir (paylaşılan akım modeli) deney grubunda biraz daha artarken, kontrol gruplarında biraz azalmıştır.

5. Soru: Şekil-1'deki devreye, Şekil-2'deki gibi özdeş bir B ampulü paralel olarak bağlanırsa, A ampulünün parlaklığı nasıl değişir?

(Bölgesel düşünme: Öğrenci, bir devrede, ampul ekleme-çıkarma gibi bir değişiklik yapıldığında, bu noktadaki değişikliğin tüm devreyi etkilediğini göz ardı etmektedir, sadece değişikliğin olduğu yere odaklanmaktadır).
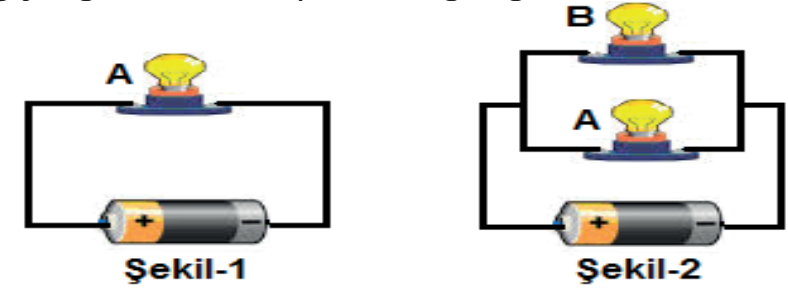
A) Değişmez
B) Artar
C) Azalır

Çünkü;

a) A ampulünden geçen akım artar.

b) A ampulünden geçen akım azalır.

c) A ampulünden geçen akım değişmez.

d) .

Beşinci sorunun analizinde; deney grubu öğrencilerinin \%13,6'sı, kontrol grubu öğrencilerinin de \%5'i ön-testin her iki aşamasında da doğru seçeneği işaretlemişlerdir. Son-testte ise her iki aşamayı da doğru cevaplayanların değeri deney grubunda \%63,6'ya, kontrol grubunda ise \%35'e çıkmıştır. Testin birinci aşamasında yer alan "azalır" ve ikinci aşamada gerekçe olarak sunulan "A ampulünden geçen akım azalır" alternatif görüşü, ön-testte bütün gruplarda oranı en fazladır. Son-testte bu alternatif fikir (bölgesel düşünme), her iki grupta büyük oranda azalmıştır.

\section{Soru: Aşağıdaki elektrik devresinde özdeş olan ampullerin parlaklıkları ile ilgili ne söylenebilir?}

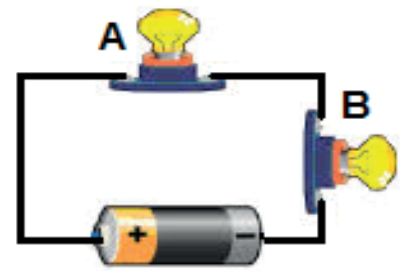

(Ampirik kural: Öğrenci, pil ile ampul arasındaki uzaklık arttıkça ampul parlaklığının azaldığını, pile yakın olan ampulün daha parlak yandığını düşünmektedir.

A) A ampulü daha parlak yanar.

B) B ampulü daha parlak yanar.

C) Her iki ampulde aynı parlaklıkta yanar.

Cünkü;

| Kastamonu Eğitim Dergisi, 27(5), 2019 | 
a) A ampulü pile daha uzak olduğu için daha parlak yanar.

b) B ampulü pile daha yakın olduğu için daha parlak yanar.

c) Ampuller özdeş olduğu için eşit parlaklıkta yanar.

d) ...

Altıncı sorunun analizinde; deney grubu öğrencilerinin \%36,4'ü, kontrol grubu öğrencilerinin de \%55'i ön-testin her iki aşamasında da doğru seçeneği işaretlemişlerdir. Son-testte ise her iki aşamayı da doğru cevaplayanların oranı deney grubunda \%91'e kontrol grubunda ise \%70'e çıkmıştı. Ön-testte deney grubunda “A ampulü pile daha uzak olduğu için daha parlak yanar" ve kontrol grubunda ise "B ampulü pile daha yakın olduğu için daha parlak yanar (ampirik kural)" alternatif görüşlerinin oranı en yüksektir. Son-testte her iki grubun alternatif fikirlerinin azaldığı görülmüştür.

7. Soru: Şekil-1'deki ampuller, Şekil-2'deki gibi bağlanırsa ampullerin parlaklıkları nasıl değişir? (Piller ve ampuller özdeştir)

(Sabit akım kaynağı: Öğrenci, pili sabit gerilim kaynağı olarak değil de sabit akım kaynağı olarak görmektedir; yani devrenin şekli ve özellikleri ne olursa olsun pillerin her devrede aynı miktarda akım oluşturduğunu düşünmektedir).

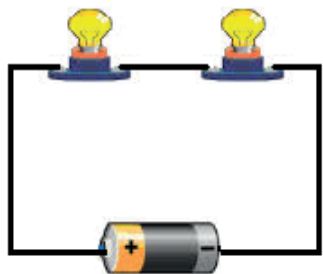

Şekil-1

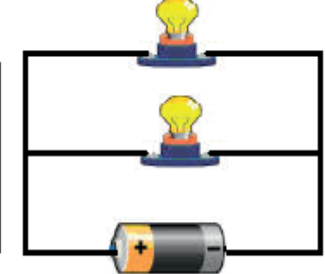

Şekil-2
A) Artar
B) Azalır
C) Değişmez

Çünkü;

a) Üzerlerinden geçen akım artacağından parlaklıkları da artar.

b) Üzerlerinden geçen akım azalacağından parlaklıkları da azalır.

c) Üzerlerinden geçen akım değişmeyeceğinden parlaklıkları da değişmez.

d)

Yedinci sorunun analizinde; deney 1 grubu öğrencilerinin \%9,1'i kontrol grubu öğrencilerinin de \%10'u ön-testin her iki aşamasında da doğru seçeneği işaretlemişlerdir. Son-testte ise her iki aşamayı da doğru cevaplayanların oranı deney grubunda \%54,6'ya kontrol grubunda ise \%50’ye çıkmıştır. Ön-testte bütün gruplarda "seri bağlı ampuller paralel bağlandığında, üzerlerinden geçen akım azalacağından parlaklıkları da azalır" ve "seri bağlı ampuller paralel bağlandığında, üzerlerinden geçen akım değişmeyeceğinden parlaklıkları da değişmez" alternatif fikirlerinin oranı en yüksektir. Son-testte her iki grubun alternatif fikirlerinin (sabit akım kaynağı modeli) azaldığı görülmüştür.

8. Soru: Şekil-1'deki gibi özdeş ampullerle kurulmuş olan devreye, Şekil-2'deki gibi özdeş üçüncü bir ampul daha eklenirse ampullerin parlaklıkları nasıl değişir?
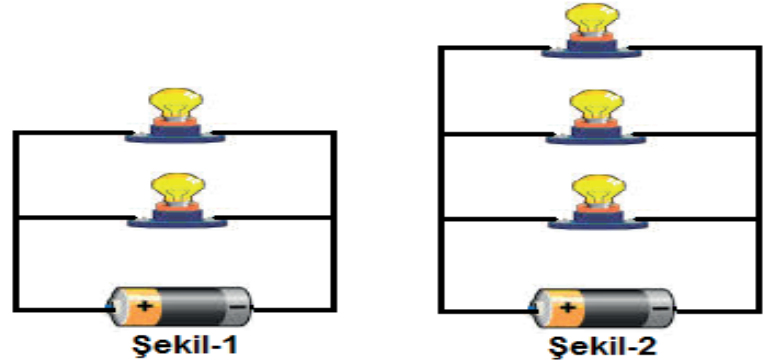

(Direnç ve toplam direnç: Öğrenci devreye yeni bir ampul eklendiğinde, ampulün bağlanma şekline bakmadan devredeki toplam direncin artacağını düşünmektedir).
A) Artar
B) Azalır
C) Değişmez

Çünkü;

a)Toplam direnç artacağından, ampullerin üzerinden geçen akım artar ve bu nedenle ampullerin parlaklıkları da artar.

b) Toplam direnç artacağından, ampullerin üzerinden geçen akım azalır ve bu nedenle ampullerin parlaklıkları da azalır.

c) Toplam direnç azalır; ama ampullerin üzerinden geçen akım değişmeyeceğinden parlaklık da değişmez.

d)

Sekizinci sorunun analizinde; deney grubu öğrencilerinin $\% 4,5^{\prime} i$, kontrol grubu öğrencilerinin de \%15'i ön-testin her iki aşamasında da doğru seçeneği işaretlemişlerdir. Son-testte ise her iki aşamayı da doğru cevaplayanla- 
rın oranı deney grubunda \%54,6'ya, kontrol grubunda ise \%25'e çıkmıştır. Ön-testte her iki grupta "paralel bağlı ampullere paralel bir ampul daha eklenirse, toplam direnç artacağından ampullerin üzerinden geçen akım azalır ve bu nedenle ampullerin parlaklıkları da azalır (direnç ve toplam direnç modeli)" alternatif fikrinin oranı en yüksektir. Son-testte bu alternatif fikrin deney grubunda büyük oranda giderildiği, kontrol grubunda ise düşük oranda giderildiği görülmüştür.

9. Soru: Özdeş ampullerle kurulmuş olan aşağıdaki devrede 1, 2 ve 3 noktalarındaki akımların büyüklüklerini ka rşılaştırınız.

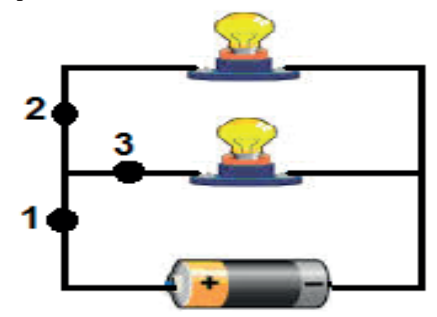

(Su akışı olarak akım yanılgısı: Öğrenci, akımın bir su borusunda olduğu gibi düz bir yolda kıvrılan yola göre daha rahat aktığı için o yolu tercih ettiğini düşünmektedir (Peşman ve Eryılmaz, 2010)).
A) $1>2>3$
B) $1>2=3$
C) $1=2=3$

Çünkü;

a) Akım kollara ayrıııken gidiş yönüne düz kola daha çok, kıvrılan kola daha az akım geçer.

b) Akım kol ayrımına geldiğinde ampuller özdeş olduğundan eşit bir şekilde iki kola ayrılır.

c) Ampuller özdeş olduğundan her noktadan eşit miktarda akım geçer.

d) .

Dokuzuncu sorunun analizinde; deney grubu öğrencilerinin \%27,3'ü, kontrol grubu öğrencilerinin de \% 10'u ön-testin her iki aşamasında da doğru seçeneği işaretlemişlerdir. Son-testte ise her iki aşamayı da doğru cevaplayanların oranı deney grubunda \%40,9'a kontrol grubunda ise \%40'a çıkmıştr. Ön-testte bütün gruplarda "akım kollara ayrılırken gidiş yönüne düz kola daha çok, kıvrılan kola daha az akım geçer (1>2>3) (su akışı olarak akım yanılgısı)" ve "ampuller özdeş olduğundan her noktadan eşit miktarda akım geçer $(1=2=3)$ " alternatif fikirlerinin oranı en yüksektir. Son-testte her iki grupta "su akışı olarak akım yanılgısı" alternatif fikrinin büyük oranda giderildiği, diğer alternatif fikrin ise deney grubunda daha da arttğı, kontrol grubunda ise çok az oranda azaldığı görülmüştür.

\section{Tartışma ve Sonuçlar}

Bu araştırmada, OBYM'ne göre yürütülen fen öğretiminin yedinci sınıf öğrencilerinin kavramsal anlamalarına olan etkisi incelenmiştir. Araştırma yarı deneysel yönteme uygun olarak yürütülmüştür. Uygulama bittikten sonra hem deney grubunun hem de kontrol grubunun EEÜKAT ön-test ve son-test puan ortalamalarına bakılmıştr. Her iki grupta da son-testteki puan ortalamalarında bir artış olduğu, deney grubunun son-test puan ortalamasının, kontrol grubuna göre daha fazla arttğı ve deney grubu lehine anlamlı bir fark olduğu bulunmuştur.

EEÜKAT'de öğrencilere 9 adet soru sorulmuş ve her bir soru ayrı ayrı incelenerek tartışılmıştr. Araştırmada öğrencilere sorulan sorulardan birincisi "aşağıdaki şekillerin hangisinde ampul ışık verir?" incelendiğinde; deney grubu öğrencileri tarafindan ön-testte en büyük oranda (14 öğrenci) doğru cevap verilen soru olmuştur. Aynı soru kontrol grubundaki 12 öğrenci tarafindan doğru cevaplanmışttr. Son-testte bu oran deney grubunda 20 öğrenci, kontrol grubunda ise 14 öğrenci tarafindan doğru cevaplandırılmıştr. Deney grubunda büyük bir artş̧ görülmüştür. Bu da kavram öğretimin arttğını göstermektedir. Ayrıca, Alternatif kavram içeren seçeneklerin işaretlenme oranı her iki grupta da azalmıştır. 2. soru "aşağıdaki elektrik devresinde ampul yanmaktadır. Ampulden geçen akım ve ampulün yanmasını açıklayan ifade hangisidir?" incelendiğinde; ön-testte deney grubu öğrencilerinin $8^{\prime} \mathrm{i}$, kontrol grubu öğrencilerinin ise 7'si tarafindan, son-testte deney grubu öğrencilerinin $18^{\prime} \mathrm{i}$, kontrol grubu öğrencilerinin ise $9^{\prime} u$ tarafindan doğru cevaplandırılmıştır. Deney grubundaki büyük artş̧ kavram öğretiminin de arttı̆ını göstermektedir. Son-testte alternatif fikir deney grubunda büyük oranda azalırken, kontrol grubunda biraz daha artmıştır. 3. soru "aşağıdaki elektrik devresinde $A$ ve $B$ ampulleri özdeştir ve her iki ampulde yanmaktadır. Buna göre devrede $A$ ampulünden geçen akım miktarı ile $B$ ampulünden geçen akım miktarı arasındaki ilişki hakkında aşağıdaki açıklamalardan hangisi doğrudur?" incelendiğin de; ön-testte deney grubu öğrencilerinin $8^{\prime} i$, kontrol grubu öğrencilerinin ise $11^{\prime} i$ tarafindan, son-testte deney grubu öğrencilerinin $19^{\prime} u$, kontrol grubu öğrencilerinin ise yine $11^{\prime} i$ tarafindan doğru cevaplandırılmıştır. Deney grubu öğrencilerinin kavram öğretimi büyük oranda gerçekleşirken, alternatif kavramlarında ise kayda değer azalmalar tespit edilmiştir. 4. soru "özdeş ampullerle kurulan aşağıdaki elektrik devresinde ampullerin parlaklıkları arasındaki ilişki nasıldır?" incelendiğinde; ön-testte deney grubu öğrencilerinin 12 'si, kontrol grubu öğrencilerinin ise $5^{\prime} \mathrm{i}$, son-testte deney grubu öğrencilerinin

|Kastamonu Eğitim Dergisi, 27(5), 2019| 
sayısı değişmezken, kontrol grubu öğrencilerinin 4'ü tarafindan doğru cevaplandırılmıştır. Deney grubu öğrencilerinin kavram öğretiminde önemli bir değişim olmazken, alternatif kavramlarında biraz arţ̧̧ görülmüştür. 5. soru "şekil-1'deki devreye, Şekil-2'deki gibi özdeş bir B ampulü paralel olarak bağlanırsa, A ampulünü parlaklığı nasıl değişir?" incelendiğinde; ön-testte deney grubu öğrencilerinin $3^{\prime} \ddot{u}$, kontrol grubu öğrencilerinin ise $1^{\prime} i$, son-testte deney grubu öğrencilerinin 14'ü, kontrol grubu öğrencilerinin ise 7'si tarafindan doğru cevaplandırılmıştr. Ön-testte deney grubu öğrencilerinin kavram öğretiminde önemli bir değişim olmazken, alternatif kavramlarında biraz artş görülmüştür. Son-testte kavram öğretimi her iki grupta artmış fakat deney grubunda bu oran daha fazladır. Ayrıca her iki grupta da alternatif kavramlarda azalma tespit edilmiştir. 6. soru "aşağıdaki elektrik devresinde özdeş olan ampullerin parlaklıkları ile ilgili ne söylenebilir?" incelendiğinde; ön-testte deney grubu öğrencilerinin $8^{\prime} i$, kontrol grubu öğrencilerinin $11^{\prime} i$, son-testte deney grubu öğrencilerinin 20'si, kontrol grubu öğrencilerinin ise 14'ü tarafindan doğru cevaplandırılmıştr. Son-testte her iki grubun kavram öğretimi artarken, alternatif fikirlerinin azaldığı görülmüştür. Ancak, deney grubunda bu oran kayda değerdir. 7. soru "şekil-1'deki ampuller, şekil-2'deki gibi bağlanırsa ampullerin parlaklıkları nasıl değişir?" incelendiğinde; ön-testte deney grubu ve kontrol grubu öğrencilerinin 2'si tarafindan son-testte deney grubu öğrencilerinin 12 'si, kontrol grubu öğrencilerinin ise 10'u tarafindan doğru cevaplandırılmıştır. Deney grubu öğrencilerinin kavram öğretimi, kontrol grubuna nazaran azda olsa gerçekleşmiştir. 8. soru "şekil-1'deki gibi özdeş ampullerle kurulmuş olan devreye, şekil-2'deki gibi özdeşüçüncü bir ampul daha eklenirse ampullerin parlaklıkları nasıl değişir?" incelendiğinde; ön-testte deney grubu öğrencilerinin 1'i tarafindan, kontrol grubu öğrencilerinin ise 3'ü tarafindan doğru cevaplandırılırken, son-testte deney grubu öğrencilerinin 12 'si, kontrol grubu öğrencilerinin ise 5 'i tarafindan doğru cevaplandırılmıştır. Kavram öğretimi deney grubu lehine büyük oranda artmış aynı zamanda alternatif fikirlerinde ise azalma tespit edilmiştir. EEÜKAT'nin son sorusu “özdeş ampullerle kurulmuş olan aşağıdaki devrede 1, 2 ve 3 noktalarındaki akımların büyüklüklerini karşılaştırınız" incelendiğinde; ön-testte deney grubu öğrencilerinin 6'sı kontrol grubu öğrencilerinin 2'si, son-testte deney grubu öğrencilerinin 9'u, kontrol grubu öğrencilerinin ise 8'i tarafindan doğru cevaplandırılmıştr. Kavram öğretimi her iki grupta artmıştır. Ancak deney grubundaki artı̧ azda olsa kontrol grubundan fazladır.

\section{5. Öneriler}

- Bu araştırmada, OBYM'nin elektrik enerjisi ünitesinde kavramsal anlamaya olan etkisi araştırılmış ve olumlu etkiye sahip olduğu görülmüştür. OBYM'nin farklı sınıf seviyelerinde, farklı konular üzerindeki etkisi araştıılabilir. Yapılan çalışmaların sayısı arttıkça, modelin yaygın etkisi hakkında daha iyi fikir edinilebilir.

- OBYM'nin kavramsal anlamaya etkisinin araştırıldığı bu araştırmada, sadece iki aşamalı ve çoktan seçmeli test kullanılmıştır. Illerde yapılacak araştırmalarda, OBYM'nin kavramsal anlamaya etkisini görebilmek için sadece bu konu üzerinde odaklanan testin yanında çizimler, mülakat vb. farklı yollarla verilerin toplandığı çalışmalar yapılabilir. Böylece, modelin kavramsal anlamaya olan etkisi daha derinlemesine irdelenmiş olur.

- OBYM ile ilgili yapılan çalışmaların çoğunlukla ortaokul seviyesinde yoğunlaştğı dikkat çekmektedir. Okul öncesi dönemde çevrelerinden birtakım bilgiler edinen öğrenciler, anaokulundan itibaren fenle karşılaşmaktadırlar. Bu nedenle, okul öncesi ve ilkokul gibi eğitimin farklı kademelerinde de OBYM'nin etkisi araştrılabilir.

\section{Kaynakça}

Akdeniz, A. R., Bektaş, U., \& Yiğit, N. (2000). İlköğretim 8. sınıf öğrencilerinin temel fizik kavramlarını anlama düzeyi. Hacettepe Üniversitesi Eğitim Fakültesi Dergisi, 19, 5-14.

Atılğanlar, N. (2014). Kavram karikatürlerinin ilköğretim yedinci sınıf öğrencilerinin basit elektrik devresi konusundaki kavram yanılgıları üzerindeki etkisi. Yüksek lisans tezi, Hacettepe Üniversitesi Eğitim Bilimleri Enstitüsü, Ankara.

Aydın, B. (2016). Illköğretim 7.sınıf öğrencilerinin elektrik enerjisi ünitesindeki başarılarına deneylerle zenginleştirilmiş gösteri yönteminin etkisi. Yüksek lisans tezi, Erciyes Üniversitesi Eğitim Bilimleri Enstitüsü, Kayseri.

Aydın, M. (2010). Fen ve teknoloji öğretiminde tahmin-gözlem-açıklama tekniğinin kullanımının kavram yanılgılarının giderilmesine ve öğrenci başarısına etkisinin araştırılması. Yüksek lisans tezi, Zonguldak Karaelmas Üniversitesi Eğitim Bilimleri Enstitüsü, Zonguldak.

Bakırcı, H. (2014). Ortak bilgi yapılandırma modeline dayalı öğretim materyali tasarlama, uygulama ve modelin etkililiğini değerlendirme. Yüksek Lisans Tezi, Karadeniz Teknik Üniversitesi Eğitim Bilimleri Enstitüsü, Trabzon.

Bakırcı, H., Artun, H., \& Şenel, S. (2016). Ortak bilgi yapılandırma modeline dayalı fen öğretiminin ortaokul yedinci sınıf öğrencilerinin kavramsal anlamalarına etkisi (gök cisimlerini tanıyalım). YYü Eğitim Fakültesi Dergisi, 13(1), 514-543.

Bakırcı, H., \& Çepni, S. (2012). Fen ve teknoloji öğretimi için yeni bir model: ortak bilgi yapılandırma modeli. X. Ulusal Fen Bilimleri ve Matematik Eğitimi Kongresi, Niğde Üniversitesi, Niğde.

Bakırcı, H., \& Ensari, Ö. (2018). Ortak bilgi yapılandırma modelinin ısı ve sıcaklık konusunda lise öğrencilerinin akademik başarılarına ve kavramsal anlamalarına etkisi. Eğitim ve Bilim, 43(196), 171-188

| Kastamonu Eğitim Dergisi, 27(5), 2019| 
Besson, U. (2004). Students' conceptions of fluids. International Journal of Science Education, 26(14), $1683-1714$.

Biernacka, B. (2006). Developing scientific literacy of grade five students: a teacher-researcher collaborative effort. Unpublished Doctoral Dissertation, Manitoba University.

Büyüköztürk, Ş. (2011). Veri analizi el kitabı. (15. Baskı), Ankara: Pegem Yayıncılık.

Chambers, S. K., \& Andre, T. (1997). Gender, prior knowledge, interest and experience in electricity and conceptual change text manipulations in learning about direct current. Journal of Researching Science Teaching, 34(2), 107-123.

Demirci, N., \& Efe, S. (2007). İlköğretim öğrencilerinin ses konusundaki kavram yanılgılarının belirlenmesi. Necatibey Eğitim Fakültesi Elektronik Fen ve Matematik Eğitimi Dergisi, 1(1), 23-56.

Dorneles, P. F. T., Veit, E. A., \& Moreira, M. A. (2010). A study about the learning of students who worked with computational modeling and simulation in the study of simple electric circuits. Revista electrónica de enseñanza de las ciencias. Ourense. 9(3), 569-595.

Duit, R., \& Treagust, D. F. (2003). Conceptual change: A powerful framework for improving science teaching and learning. International Journal of Science Education, 25, 671-688.

Ebenezer, J., Chacko, S., Kaya, O. N., Koya, S. K., \& Ebenezer, D., L. (2010). The effects of common knowledge construction model sequence of lessons on science achievement and relational conceptual change. Journal of Research in Science Teaching, 47(1), 25-46.

Ebenezer, J., \& Connor, S. (1998). Lerning to teach science: a model for the 21st century. Prentice Hall: USA.

Gilbert, J. K., Osborne, R. J., \& Fensham, P. (1982). Children's science and its consequences for teaching. Science Education, 66(4), 623-633.

Gobert, J. D., \& Clement, J. J. (1999). Effects of student-generated diagrams versus student-generated summaries on conceptual understanding of causal and dynamic knowledge in plate tectonics". Journal of Research in Science Teaching, 36(1), 39-54.

Gök, Ö., Doğan, A., Doymuş, K., \& Karaçöp, A. (2009). İşbirlikli öğrenme yönteminin ilköğretim öğrencilerinin akademik başarılarına ve fene olan tutumlarına etkileri. Gazi Eğitim Fakültesi Dergisi, 29(1), 193-209.

Hewson, P. W. (1992). Conceptual change in science teaching and teacher education. Paper presented at a meeting on "Research and Curriculum Development in Science Teaching," under the auspices of the National Center for Educational Research, Documentation, and Assessment, Ministry for Education and Science, Madrid, Spain

Hewson, P. W., \& Hewson, M. G. A. (1988). An appropriate conception of teaching science: A view from studies of science learning. Science Education, 72(5), 597-614.

İyibil, Ü. G. (2011). A new approach for teaching 'energy' concept: The common knowledge construction model. World Conference on New Trends in Science Education (WCNTSE), 19-23 September 2011, Kuşadası, Turkey.

Kıryak, Z. (2013). Ortak bilgi yapılandırma modelinin 7. Sınıf öğrencilerinin su kirliliği konusundaki kavramsal anlamalarına etkisi. Yüksek Lisans Tezi, Karadeniz Teknik Üniversitesi Eğitim Bilimleri Enstitüsü, Trabzon.

Küçük, Z. (2011). Zenginleştirilmiş 5E modelinin 7. sınıf öğrencilerinin kavramsal değişimine etkisi: elektrik akımı örneği. Yüksek lisans tezi, Karadeniz Teknik Üniversitesi Eğitim Bilimleri Enstitüsü, Trabzon.

McKillup, S. (2012). Statistics explained: An introductory guide for life scientists (Second edition). United States: Cambridge University Press.

Osborne, R. (1983). Towards Modifying Children's Ideas About Electric Current. Research in Science and Technological Education, 1(1), 73-83.

Peşman, H., \& Eryılmaz, A. (2010). Devolepment of a three-tier test to assess misconception about simple electric circuits. The Journal of Educational Research, 103, 208-222.

Posner, G. J., Strike, K. A., Hewson, P. W., \& Gertzog, W. A. (1982). Accommodation of a scientific conception: Toward a theory of conceptual change. Science Education, 66(2), 211-227.

Psillos, D., \& Kariotoglou, P. (1999). Teaching Fluids: Intended knowledge and students! actual conceptual evolution. International Journal of Science Education, 21(1), 17-38.

Sencar, S., \& Eryılmaz, A. (2002). Cinsiyetin dokuzuncu sınıf öğrencilerinin elektrik devreleri konusunda sahip oldukları kavram yanılgılarının farklı alt kategorilerine etkisi. V. Ulusal Fen Bilimleri ve Matematik Eğitimi Kongresi, Tam Metin Kitabı, Ankara.

Sencar, S., Yılmaz, E. E., \& Eryılmaz, A. (2001). Lise öğrencilerinin basit elektrik devreleri ile ilgili kavram yanılgıları. Hacettepe Üniversitesi Eğitim Fakültesi Dergisi, 21, 113-120.

Shadish, W. R., Cook, T. D., \& Campbell, D. T. (2002). Experimental and quasi experimental designs for generalized causal inference. New York: Houghton Mifflin.

Shapiro, S. S., \& Wilk, M. B. (1965). An analysis of variance test for normality (Complete samples). Biometrika, 52(3/4), 591-611.

| Kastamonu Eğitim Dergisi, 27(5), 2019| 
She, H. C. (2002). Concepts of higher hierarchical level require more dual situated learning events for conceptual change: a study of air pressure and buoyancy. International Journal of Science Education, 24(9), 981-996.

Sinan, O. (2007). Fen bilgisi öğretmen adaylarının proteinler ve protein sentezi ile ilgili kavramsal anlamaları. Doktora tezi, Balıkesir Üniversitesi Fen Bilimleri Enstitüsü, Balıkesir.

Ünal-Çoban, G. (2009). Modellemeye dayalı fen öğretiminin öğrencilerin kavramsal anlama düzeylerine, bilimsel süreç becerilerine, bilimsel bilgi ve varlık anlayışlarına etkisi: 7. sınıf ışık ünitesi örneği. Doktora tezi, Dokuz Eylül Üniversitesi Eğitim Bilimleri Enstitüsü, İzmir.

Ünsal, Y., \& Güneş, B. (2003). İlköğretim 6. sınıf fen bilgisi ders kitabının fizik konuları yönünden incelenmesi. Gazi Eğitim Fakültesi Dergisi, 23(3), 115-130.

Vural, S., Demircioğlu, H., \& Demircioğlu, G. (2012). Genel bilgi yapılandırma modeline uygun geliştirilen bir öğretim materyalinin üstün yetenekli öğrencilerin asit baz kavramlarını anlamaları üzerine etkisi. IV. Uluslararası Türkiye Eğitim Araştırmaları Kongresi, Yıldız Teknik Üniversitesi, 4-7 Mayıs 2012, İstanbul.

Wang, T., \& Andre, T. (1991). Conceptual change text versus traditional text and application question versus no questions in learning about electricity. Contemporary Educational Psychology, 16, 103-116.

Wood, L. C. (2012). Conceptual change and science achievement related to a lesson sequence on acids and bases among African American alternative high school students: A teacher's practical arguments and the voice of the "other". Unpublished Ph.D. dissertation, Wayne State University, Michigan.

Wood, L., Ebenezer, J., \& Boone, R. (2013). Effects of an intellectually caring model on urban African American alternative high school students' conceptual change and achievement in chemistry. The Royal Society of Chemistry, Chemistry Education Reaerch and Practice.

Yıldırım, A., \& Şimşek, H. (2006). Sosyal bilimlerde nitel araştırma yöntemleri. Ankara: Seçkin Yayıncılık.

Yıldırım, H. İ., Yalçın, N., Şensoy, Ö., \& Akçay, S. (2008). İlköğretim 6., 7. ve 8. sınıf öğrencilerinin elektrik akımı konusunda sahip oldukları kavram yanılgıları. Kastamonu Eğitim Dergisi, 16(1), 67-82.

Yılmaz, H., \& Huyugüzel-Çavaş, P. (2006). 4-E öğrenme döngüsü yönteminin öğrencilerin elektrik konusunu anlamalarına olan etkisi. Türk Fen Eğitimi Dergisi, 3(1), 2-18.

Yürümezoğlu, K., \& Çökelez, A. (2010). Akım geçiren basit bir elektrik devresinde neler olduğu konusunda öğrenci görüşleri. Türk Fen Eğitimi Dergisi, 7(3), 147-166. 